\title{
A Practical Guide to Rodent Islet Isolation and Assessment Revisited
}

\author{
Kathryn L. Corbin ${ }^{1,2}$, Hannah L. West ${ }^{3}$, Samantha Brodsky ${ }^{1,2}$, Nicholas B. Whitticar ${ }^{2,4}$, William J. Koch ${ }^{1,2,4}$ and
} Craig S. Nunemaker ${ }^{1,2,5^{*}}$

\begin{abstract}
Insufficient insulin secretion is a key component of both type 1 and type 2 diabetes. Since insulin is released by the islets of Langerhans, obtaining viable and functional islets is critical for research and transplantation. The effective and efficient isolation of these small islands of endocrine cells from the sea of exocrine tissue that is the rest of the pancreas is not necessarily simple or quick. Choosing and administering the digestive enzyme, separation of the islets from acinar tissue, and culture of islets are all things that must be considered. The purpose of this review is to provide a history of the development of islet isolation procedures and to serve as a practical guide to rodent islet research for newcomers to islet biology. We discuss key elements of mouse islet isolation including choosing collagenase, the digestion process, purification of islets using a density gradient, and islet culture conditions. In addition, this paper reviews techniques for assessing islet viability and function such as visual assessment, glucosestimulated insulin secretion and intracellular calcium measurements. A detailed protocol is provided that describes a common method our laboratory uses to obtain viable and functional mouse islets for in vitro study. This review thus provides a strong foundation for successful procurement and purification of high-quality mouse islets for research purposes.
\end{abstract}

Keywords: Islets of Langerhans, Isolation, Beta cell, Collagenase, Density gradient, Neonatal, Calcium, Insulin secretion

\section{Introduction}

In early 1869 , with his mention of "small cells of almost perfect homogeneous content, and of perfect polygonal form ... lying together in twos or in small groups," [1] Paul Langerhans quietly announced to the medical community the discovery of what would later become known as the "islets of Langerhans". This announcement would also set in motion the groundwork for successfully treating diabetes mellitus [2,3]. At the time of the discovery, the function of these small clusters of cells was unknown, and Langerhans did not speculate about it. Twenty years would elapse between Langerhan's initial

\footnotetext{
* Correspondence: nunemake@ohio.edu

${ }^{1}$ Heritage College of Osteopathic Medicine, Ohio University, Athens, OH, USA 2Department of Biomedical Sciences, Ohio University, Athens, OH, USA

Full list of author information is available at the end of the article
}

discovery and the connection between the pancreas (and by default, islets) and diabetes was clearly established by Oskar Minkowski and Josef von Mering in 1889 [4]. By 1893, Gustave Édouard Laguesse hypothesized that the islets of Langerhans produced "internal secretions" that Jean de Meyer named "insulin" in 1909 [5]. Attempts to isolate this "internal secretion" began as early as 1907 but were not successful until the 1920s when insulin was first used to treat diabetes in a human patient $[2,5]$.

It was hypothesized that the exocrine tissue would impair the vitality and function of the endocrine pancreas [5, 6]. In 1902, Leonid W. Ssobolew suggested that the separation of the exocrine pancreas from the endocrine would increase islet viability and improve success in transplantation procedures $[5,6]$. To this end, R. R. Bensley pioneered the staining of islets using neutral red

(c) The Author(s). 2021 Open Access This article is licensed under a Creative Commons Attribution 4.0 International License, which permits use, sharing, adaptation, distribution and reproduction in any medium or format, as long as you give appropriate credit to the original author(s) and the source, provide a link to the Creative Commons licence, and indicate if changes were made. The images or other third party material in this article are included in the article's Creative Commons licence, unless indicated otherwise in a credit line to the material. If material is not included in the article's Creative Commons licence and your intended use is not permitted by statutory regulation or exceeds the permitted use, you will need to obtain permission directly from the copyright holder. To view a copy of this licence, visit http://creativecommons.org/licenses/by/4.0/. The Creative Commons Public Domain Dedication waiver (http//creativecommons.org/publicdomain/zero/1.0/) applies to the data made available in this article, unless otherwise stated in a credit line to the data. 
and hand picking $[5,7]$. But here the isolation process languished until 1964, when Claes Hellerström developed a technique using microscope microdissection [8]. In swift succession, beginning in 1965, isolation techniques evolved using collagenase [9], utilizing the anatomy of the pancreas in 1967 [10], and a density gradient in 1969 [11]. These three techniques were finally pulled together in 1985 by Gotoh et al [12] and truly opened the way for islet transplantation and in-depth study of islets.

Figure 1 shows this flow of advances in islet isolation. Since that time, there have been no major changes in the basic approach to islet isolation procedures. Our lab provided "A Practical Guide to Rodent Islet Isolation", describing our insights into these procedures in 2009 [13]. Other groups have looked at a variety of digestive enzymes [14-16], variations on delivery of digestive enzyme [14, 17], and the separation of islets from exocrine tissue [18-20]. Some researchers have advocated the use of filtration to purify islets, skipping the density gradient completely $[21,22]$. There have also been efforts to use stem cells [23-25] or dissociated islet cells and human amniotic epithelial cells [26], thus attempting to reduce or eliminate the need for islet isolations.

Islet isolation was pioneered in a very narrow range of species, specifically guinea pigs $[7,9-11,27,28]$ and mice $[8,12]$, with mice and rats still being the most often used species [16, 29-31]. Pigs [25], goats [32], cats [33], monkeys [34, 35], and dogs [36, 37] are also used to study various aspects of diabetes and potential treatments.

The primary goal of islet isolation, whether for in vitro studies or for transplantation, is to obtain purified islets that are both viable and responsive to stimulation in a manner consistent with their function in vivo. To this end, we highlight three key elements of a successful islet isolation procedure: 1) Digesting the tissues connecting the islets to the exocrine tissue, 2) separating islets from non-islet tissue, and 3) culturing islets in an environment that maintains viability and function (Fig. 2). This paper will review these key elements and provide detailed methods used in our laboratory to consistently procure viable and functional islets for research. Our protocols are by no means the only successful methods for the isolation of pancreatic islets; however, the additional details provided in these protocols for each step will hopefully assist researchers in their efforts to obtain a large number of healthy islets for both study and transplantation.

\section{Procedures of Islet Isolation Basic Methodologies}

When assessing and evaluating any islet isolation protocol consideration must be given to differences in the type and concentration of collagenase, the method of administration of the collagenase, temperature and duration of the digestion phase, the method used to purify islets from pancreatic acinar tissue, and the culture conditions following isolation. Each of these considerations are discussed below. While these items were discussed in our previous guide [13], each has been expanded, providing more up to date information for those who are new to the study of islets.

A survey of the literature for rodent islet isolation reveals a variety of methods for delivering the digestive enzymes to the pancreatic tissue surrounding the islets as

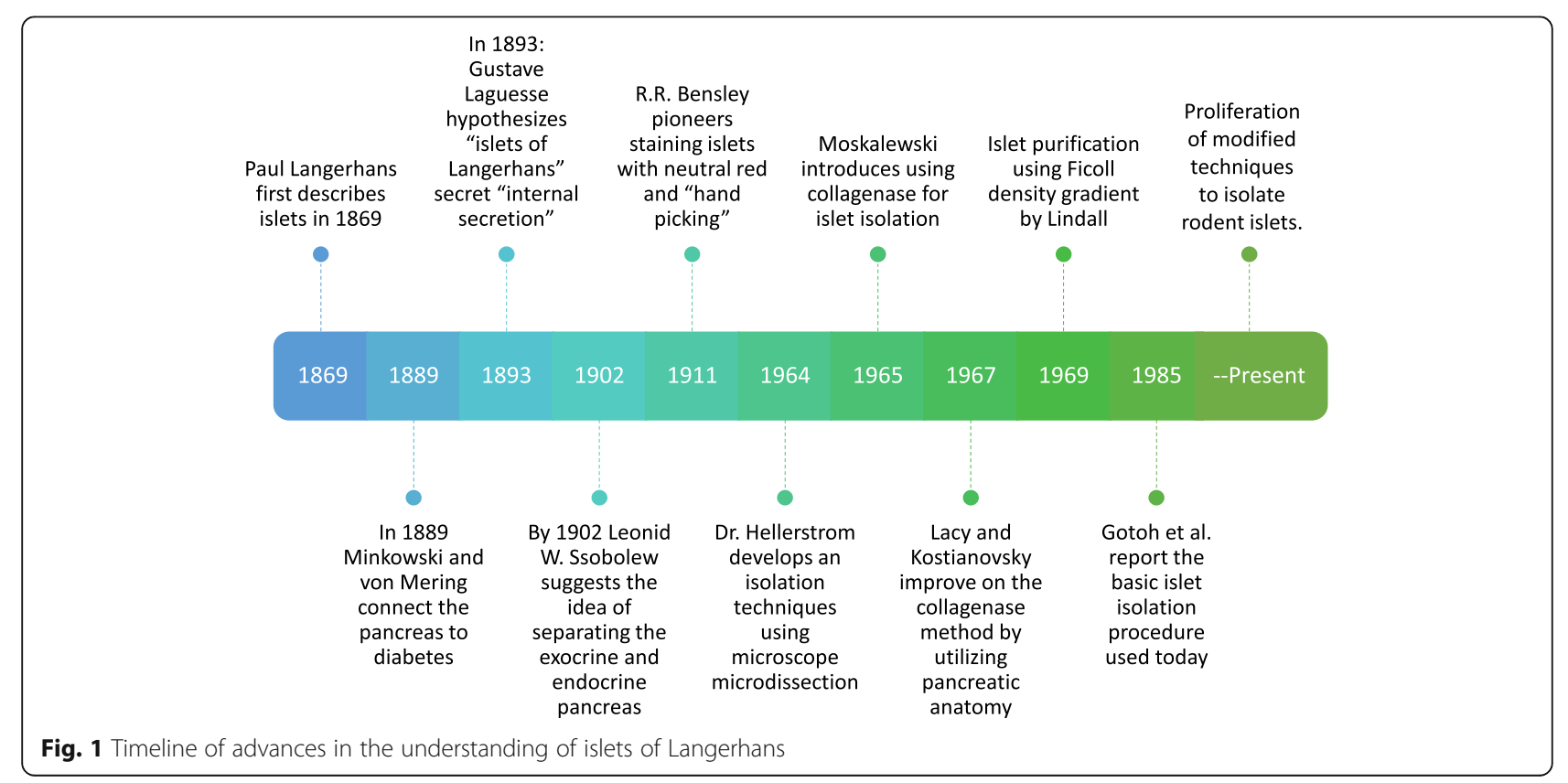




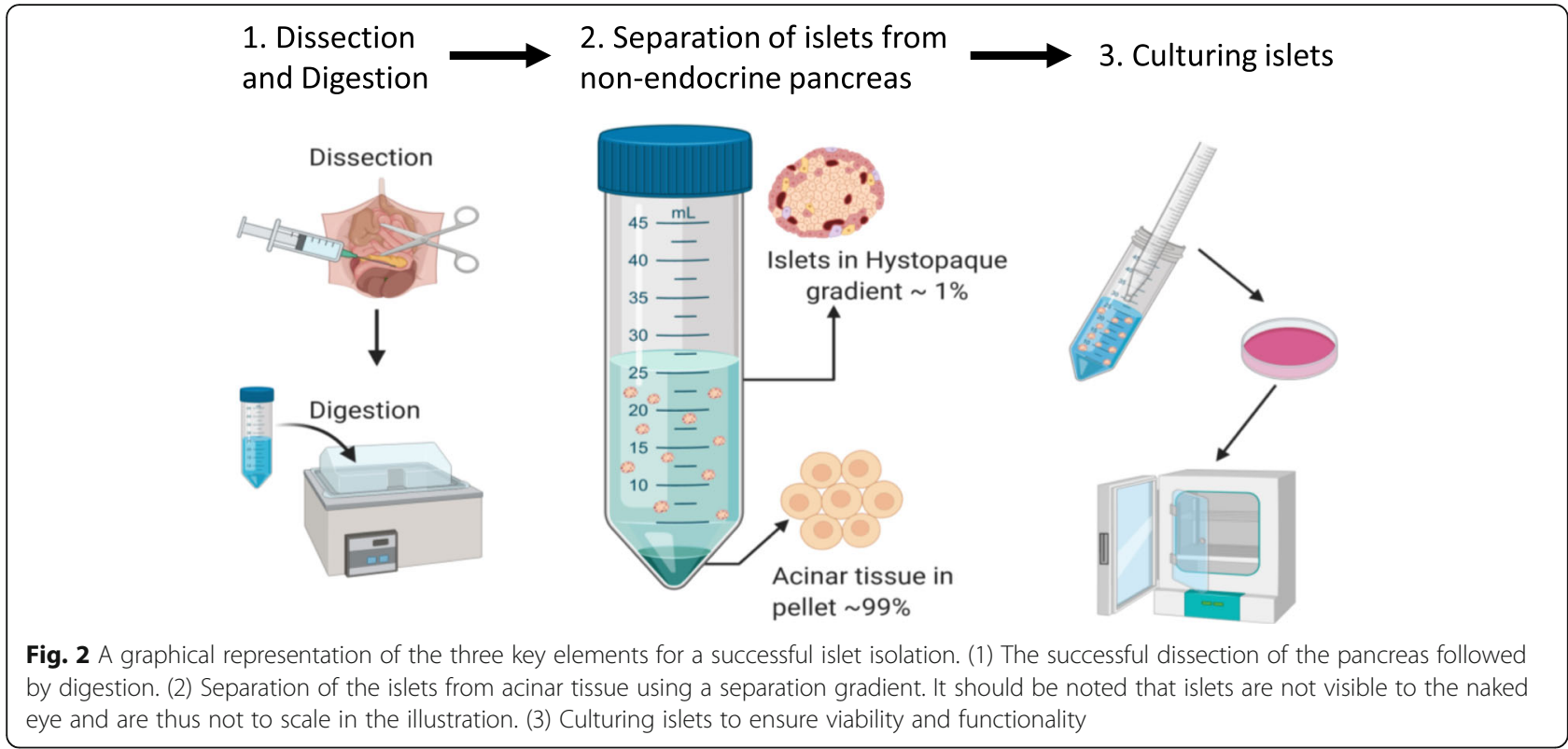

well as different digestive enzymes. One method of delivery is to excise the pancreas from a euthanized animal and cut it into pieces, increasing the exposed surface area and providing improved conditions for the digestive enzyme to break down the tissue surrounding the islets $[10,17,38]$. The pieces are then enzymatically digested in the solution while also being mechanically digested by either shaking or stirring. A second method, described by Gotoh et al, has collagenase injected into the common bile duct of a euthanized animal. The inflated pancreas is then excised and digested at $37^{\circ} \mathrm{C}$ without being cut into pieces or the addition of mechanical digestion [39].

While these two approaches form the foundation of many islet isolation techniques, there are considerable variations among published methods as well as alternative methods $[8,16,20,29,40-43]$. The advantages of using the common bile duct are twofold: 1 ) it allows the digestive enzyme to access the islets using the anatomical structures of the pancreas, and 2) stationary digestion reduces mechanical damage to the islets. Our laboratory uses a modification of the common bile duct protocol when isolating rodent islets using collagenase (see Appendix A for an annotated murine protocol and Appendix B for a bullet point protocol). Although cannulation of the murine bile duct requires technical skill, we are partial to this approach, as the collagenase interacts more closely with the connective tissue surrounding the islets when it is delivered through the intact pancreatic ductal system [44-46], resulting in a greater number of successfully isolated islets. There are several detailed online video accounts of a rodent islet isolation using a method of bile duct cannulation [16, 29, 30, 47-49].

\section{Collagenase - Selection and Use}

Collagenases are proteolytic enzymes that digest collagen, a major structural protein in animals $[50,51]$ and have been found in everything from bacteria to mammals [50-53]. Out of all the potential sources, it was found that all collagens or collagen-like proteins are susceptible to the enzyme obtained from Clostridium histolyticum (Cl. histolyticum) [51], the bacterium from which collagenase was first purified in the 1950s [54]. Subsequent studies found the raw collagenase obtained from this bacterium is a mixture of several different collagenases distinguished by molecular mass, termed alpha, beta, gamma, delta, epsilon, zeta, and eta $[55,56]$. These have been at least partially characterized for stability and specificity [54, 55, 57-61]. It was also found that these collagenases could be separated into two distinct classes based on substrate specificity and amino acid analysis [58]. Class I collagenase encompasses the isoforms designated alpha, beta, gamma, and eta [56]. These four have high collagenase activity and moderate activity on the synthetic peptide 2-furanacryloyl-Lleucylglycyl-L-prolyl-L-alanine (FALGPA) [62]. The class II collagenases are delta, epsilon, and zeta [56] and have moderate collagenase activity and high FALGPA activity [62]. After these classifications were made, it was found that $\mathrm{Cl}$. histolyticum has two distinct, yet separate genes that code for collagenase. The gene designated colG codes for those collagenases in class I while the $\mathrm{colH}$ gene codes for class II collagenases [63]. Since it is difficult to completely purify one type of collagenase from another, and the enzymes act synergistically, characterization is of vital importance. 
Since collagenase is purified from bacterial culture, considerable variability exists between manufacturers as well as between production lots of collagenase from the same manufacturer. Therefore, the formulation, enzyme activity and purity of a given lot all strongly influence the outcome of any islet isolation. The composition of the collagenase and the concentration of enzymes in a specific lot must therefore be ideally suited to the task of islet isolation. A detailed description of the differences in isolation with purified collagenase type I and II as well as the combination that yields the most effective isolation of rat islets have been described by Wolters et al $[64,65]$. Others formulated criteria for evaluating each lot of commercially available collagenase to ensure proper digestion of rat islets [66]. Those collagenase formulations with increased collagenase activity, low levels of trypsin activity, and a specific range of both neutral proteases and clostripain may yield the most viable islets $[64,66]$. Our lab has found that optimal collagenase formulations used for rat islet isolation also provide acceptable criteria for rating collagenase used in our mouse islet isolation procedure.

Thus, there is a remarkable range of digestive enzyme formulations available for islet isolation, from crude collagenases to highly purified combinations used extensively for human islet transplantation. It has been suggested that the differences from lot to lot may be due to the lack of proper measurement of trypsin-like activity, even in the highly purified mixtures used in the isolation of human islets for transplantation [67]. Brandhorst et al suggested the trypsin-like activity in enzyme blends may work in concert with the other enzymes to increase the activity of the digestion, but there is some debate about the damage the trypsin-like activity has on the islets [68]. To ensure consistent activity and reproducibility for human islet isolation, the enzyme blends with both high purity and a precise notation of components are used, such as collagenase NB1 (Nordmark, Uetersen, Germany), Liberase (Roche, Basel, Switzerland) and Vitacyte HA (Vitacyte, Indianapolis, IN, USA) [67, 69-71]. These higher purity, and consequently high priced, enzymes are also used in human islet isolation to reduce the incidence of contamination by endotoxins [71, 72].

It has been shown that the presence of endotoxins correlates with an increase of the proinflammatory cytokines interleukin-1beta (IL-1beta), interleukin-6 (IL-6), and tumor necrosis factor-alpha (TNF-alpha) in both rat and human islets $[69,73,74]$. Both collagenase formulations and the different types of gradient compounds have been found to contain endotoxin in varying amounts [69]. Endotoxins are of particular concern in human islet transplant procedures especially since the infiltration of inflammatory cytokines in transplanted islets has been linked to endotoxin contamination in both enzyme blends and separation gradients $[19,69,73,74]$.

\section{The Process of Collagenase Digestion}

The process of collagenase digestion is of the utmost importance to the success of any given protocol. To ensure success, consideration must be given to the type of collagenase, its activity, the concentration of the collagenase solution, its route of administration, and the duration and temperature of the digestion. These factors can all vary widely among the various protocols. Clamping or tying off the ampulla of Vater where the hepatopancreatic duct connects to the duodenum (at the sphincter of Oddi) and perfusing the pancreas through the common bile duct allows collagenase to access the islets using the biological structures of the pancreas (Fig. 3). This method may change the duration of the digestion when compared to other methods. Differences in composition between lots of collagenase and other factors influence digestion as well. Thus, it is important to test each protocol for optimal viability and islet function, both of which remain paramount to the success and reproducibility of islet isolation.

The duration of collagenase exposure is particularly important and should be optimized for each production lot. Figure 4 shows islets immediately post-separation when digestion time is not optimized to the unique collagenase lot. Digestion temperature, collagenase concentration, and route of administration were all the same; only digestion time was altered. In Fig. 4a, digestion time was not sufficient to separate the islets from the acinar tissue, resulting in clumping from which the islets will be difficult if not impossible to remove. These grossly encumbered islets will not be suitable for experiments. Figure $4 \mathrm{~b}$ shows heavily over digested islets. Islets that have been over digested are fewer in number and typically either very large or very small. There also tends to be much finer debris in the plate as the islets will shed dead and dying cells for some time. In our experience, over digested islets are not as responsive to stimulation and do not survive overnight culture well.

Our lab, following published guidelines for collagenase enzyme formulations [66], uses Collagenase P (Roche, Basal, Switzerland, \#11249002001) enzyme at $1.4 \mathrm{mg} / \mathrm{mL}$ in a modified Hank's Balanced Salt Solution (HBSS) (Invitrogen, Carlsbad, CA, USA, \#14065-056), injected into the pancreas via the common bile duct. The pancreas is then excised whole and placed in modified HBSS for stationary digestion at $37^{\circ} \mathrm{C}$ for seven to $10 \mathrm{~min}$ as described in detail in Appendix A. Ideally, three separate digestions using two mice per time point should be completed to evaluate a newly purchased lot of collagenase. Our lab uses timepoints of 7, 8, and $9 \mathrm{~min}$. After overnight incubation, islets from each digestion should 


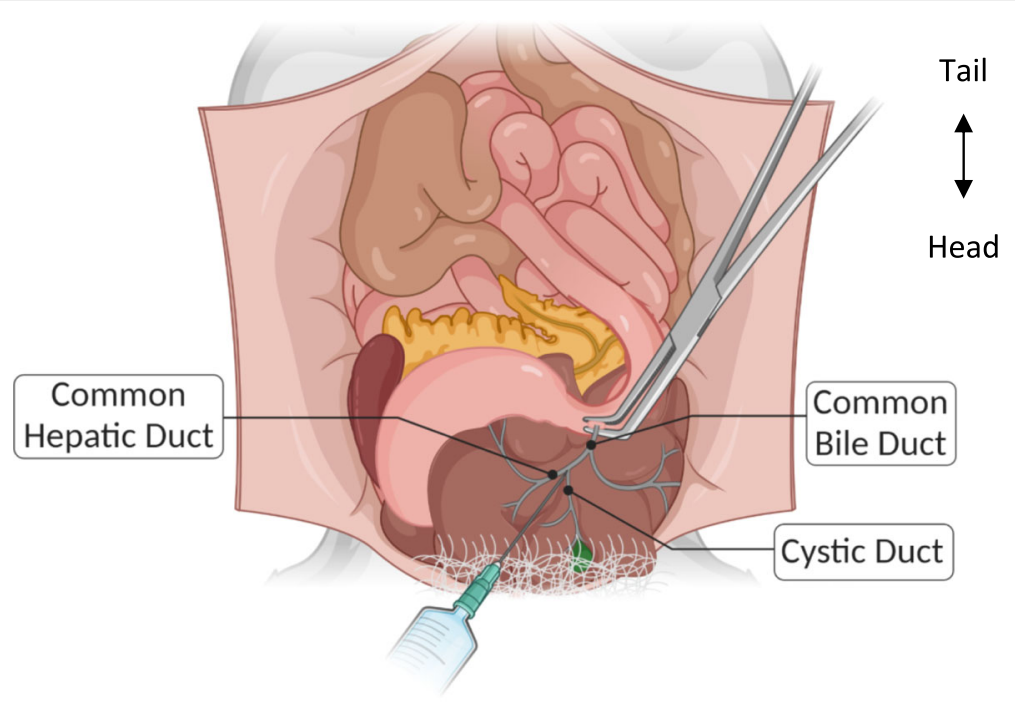

Fig. 3 Anatomy of the mouse upper intraperitoneal cavity showing the injection site and clamping of the common bile duct at the duodenum. NOTE: The top is the caudal portion of the mouse, bottom is the rostral portion, i.e., this is from the perspective of the mouse lying on its back tail away from the surgeon and nose toward the surgeon.

be visually inspected and tested for viability and functionality using the assays reviewed below. The group with the highest yield (assuming proper cannulation) and best outcome in the assays indicates the proper digestion time.

\section{Separation of Islets and Pancreatic Acinar Tissue Using a Density Gradient}

Purifying islets from acinar tissue, regardless of the method used, is important due to the nature of pancreatic tissue. The cells of the exocrine pancreas secrete various digestive enzymes that negatively impact islet viability [75]. Our lab has used both Ficoll 400 (MilliporeSigma, Burlington, MA) and Histopaque (MilliporeSigma, Burlington, MA) at different densities. In isolations using Ficoll 400 layered in a discontinuous gradient of $1.109,1.096,1.070$, and $0.570 \mathrm{~g} / \mathrm{ml}$, islets were recovered from the interfaces of both the 1.070/ 1.096 and $1.096 / 1.109 \mathrm{~g} / \mathrm{ml}$ layers. We found, however, that the preparations were often contaminated with acinar tissue. Using aseptically filled and premixed Histopaque, a mixture of sodium diatrizoate and Ficoll 400, we found that our purity results generally improved. Combining Histopaque $1.119 \mathrm{~g} / \mathrm{mL}$ with the $1.077 \mathrm{~g} / \mathrm{mL}$ preparation to produce a $1.100 \mathrm{~g} / \mathrm{mL}$ gradient appears to enhance islet purity. It should be noted that our studies comparing Histopaque and Ficoll were not rigorous, and both gradients are widely used and accepted. McCall et al compared Histopaque, Ficoll, Dextran and Iodixanol assessing recovery, viability, purity, and in vitro functionality [76].
Depending on how much residual acinar tissue remains following the initial purification of the islets, a second purification is often needed to further increase the purity prior to culture. Our protocol includes using a basic light microscope with a $4 \mathrm{x}$ objective to identify islets, then handpicking those islets from one suspension culture dish into a second culture dish. Ideally, this is done $2 \mathrm{~h}$ post isolation. The islets then recover overnight in a $37{ }^{\circ} \mathrm{C}$ incubator with $5 \% \mathrm{CO}_{2}$. The following morning, the islets are again handpicked into a new dish, thus eliminating any acinar tissue that may have either been transferred with the initial cleaning or was attached to the islets after isolation. This also removes healthy islets from any buildup of toxins from dying acinar tissue and from any necrosing islets that did not survive. It should be stated that once the islets are transferred to media, minimizing time outside the temperaturecontrolled and sterile conditions of the incubator will limit contamination and $\mathrm{pH}$ changes while handpicking islets for experiments.

\section{Islet Yields}

Overall yield from a rodent pancreas is highly variable among strains. A comparison of seven different mouse strains was made by Bock et al and the number of islets per pancreas was found to range from $\sim 1000$ in 129 S6 mice to $\sim 2500$ in B6 mice [77]. Using a mouse model of diabetes, they identified a similar number of islets per pancreas $(\sim 3200)$ for both the ob/ob and the ob/+ controls [78]. More recently, Mitok et al reported the average islet yield for eight different strains of mice, with > 400 islets/mouse from five of the strains (B6, A/J, WSB, 


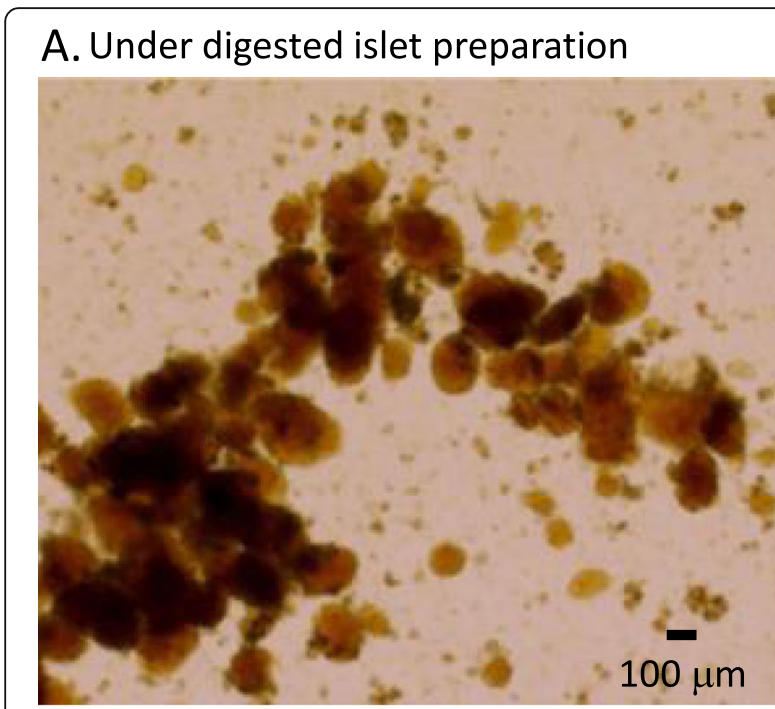

\section{B. Over digested islet preparation}

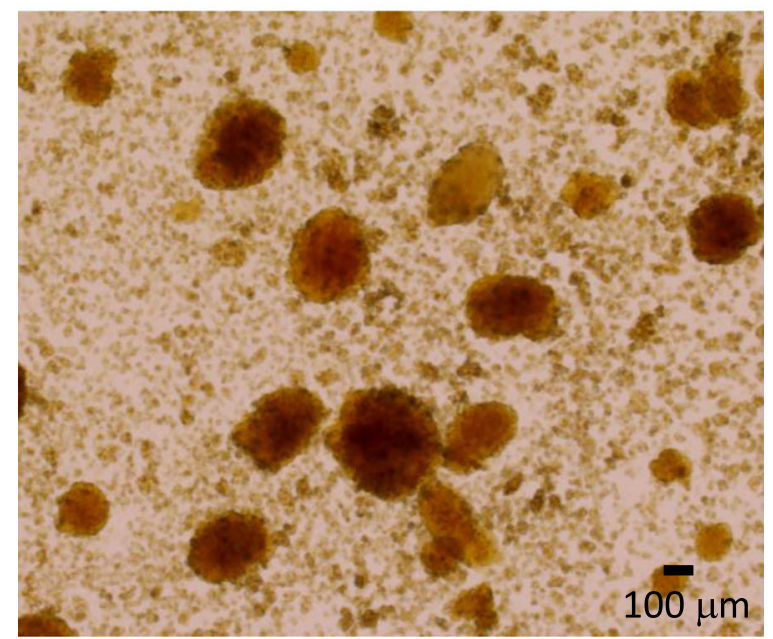

Fig. 4 Examples of both under digested and over digested islets immediately post isolation and purification. a Under digested islets will typically contain large amounts of acinar tissue appearing dark brown or black. Islets are often aggregated near the masses of acinar tissue as shown. Separating islets from these under digested clumps is often difficult. b Over digested islet preparations result in large amounts of pancreatic debris consisting of tiny fragments of acinar tissue and digested islets

CAST, and PWK), <300 islets/mouse for the 129 and NOD strains, and notable sex differences in islet yield for the NZO strain [31]. De Haan et al investigated yields from different rat strains as well as factors that potentially influenced yields [66]. Inuwa et al demonstrated that the total number of islets in young male Wistar rats increased with age, ranging from $\sim 6000$ to $\sim 20,000$ islets per pancreas [79], while others have estimated the number per rat pancreas as low as $~ 3000$ 5000 islets $[80,81]$. Thus, the expected islet yield from an isolation procedure depends a great deal on the age, sex, and strain of the rodent.
The expertise of the technician, as well as the method of isolation chosen, will also influence the total islet yield, making a definitive expected yield difficult to quantify. In our lab an experienced technician using 812-week-old CD-1 mice (Envigo, Indianapolis, IN) will usually obtain between 300 and 450 islets on average, while a similarly aged C57BL/6 J (Jackson Laboratory, Bar Harbor, ME) will yield only 250-350 islets with an average yield of 300 islets per mouse. De Groot et al report rat yields of approximately $600-800$ islets per animal [82]. Since the endocrine pancreas accounts for between 1 and $4 \%$ of the total volume of the pancreas [83], this suggests islet yields range from 10 to $30 \%$ from a typical rodent pancreas. For comparison, it is thought the human pancreas contains over one million islets, yields of approximately 250,000-300,000 islets are estimated by islet equivalents (IEQ) [84], although there are notable issues with IEQ quantification and no clear consensus on islet yields from human donors [85].

\section{Conditions for Islet Culture}

While our previous guide [13] contained information on conditions for islet culture, this guide has expanded that information as well as provided visual representations for islets at three different time points post-isolation. After an islet isolation, it is vital to ensure proper culture conditions so islets may recover from the process of collagenase digestion. An examination of media with different glucose concentrations showed that rat and mouse islets cultured with $11 \mathrm{mM}$ glucose have lower apoptosis rates, increased viability, and increased immunoreactive insulin compared to islets cultured in either higher or lower glucose concentrations [86, 87]. Culture media with glucose concentrations substantially below $11 \mathrm{mM}$ can reduce the insulin content in the islet as well as downregulate key genes related to glucose metabolism, whereas prolonged exposure to high glucose may lead to toxicity or other functional impacts [87-89]. Of all the culture media tested, RPMI 1640 supplemented with serum best maintained or augmented glucose-stimulated insulin secretion in murine islets [86]. Other groups have reported success in maintaining viability and function with rat islets in CMRL 1066 [66] and Iscove's MEM [90].

Our lab uses RPMI 1640 (Invitrogen, Carlsbad, CA, USA \#11875-093) culture media supplemented with $10 \%(\mathrm{v} / \mathrm{v})$ fetal bovine serum (R\&D Systems, Minneapolis, MN, USA \#S11150) to promote viability and $100 \mathrm{U} /$ $\mathrm{mL}$ penicillin and $100 \mathrm{mg} / \mathrm{mL}$ streptomycin (Invitrogen, Carlsbad, CA, USA \#15140-122) to reduce contamination both for culturing of islets and while purifying islets from acinar tissue after density gradient separation. Islets are plated in $100 \mathrm{~mm} \times 20 \mathrm{~mm}$ suspension culture dishes (Corning Inc., Corning, NY, \#430591) as 


\section{A. Immediately after isolation}

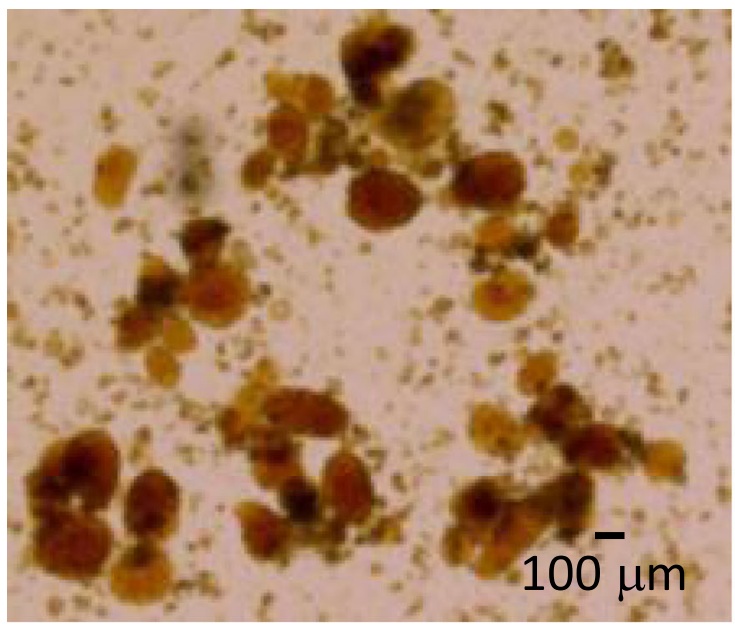

\section{B. Two-hour post isolation}

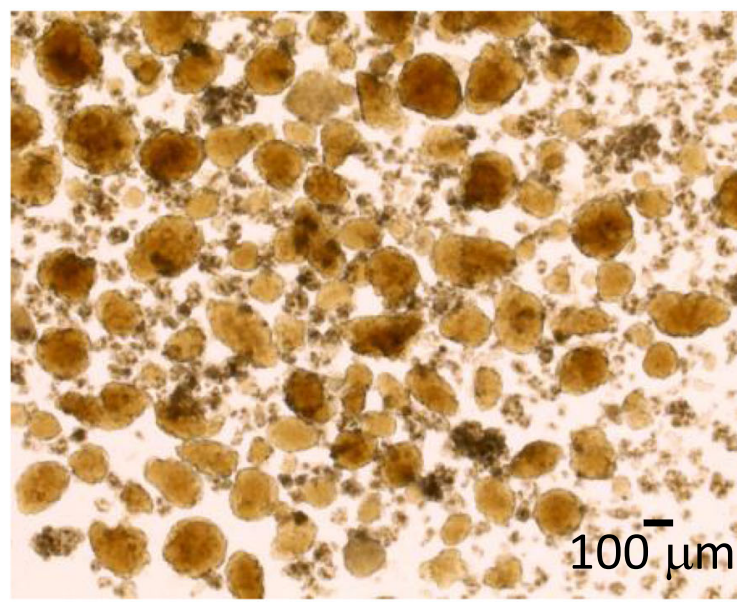

\section{Overnight recovery \& cleaning}

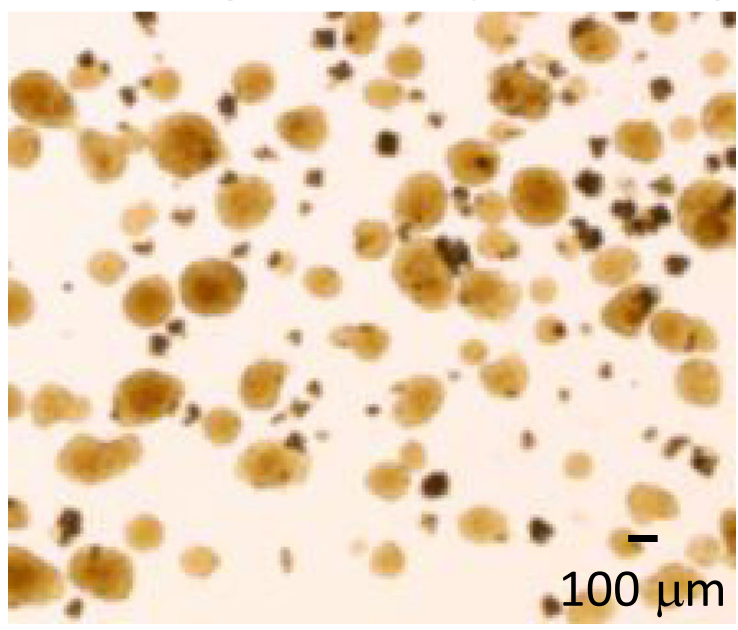

Fig. 5 Islets after optimal digestion and recovery time. a An example of islets immediately post-isolation and purification. b-c The same preparation of islets after a two-hour recovery period but before cleaning (b) and after overnight recovery and before a final cleaning (c). Note that 88 islets were counted in (b) and 80 islets in (c) even though the tissue density appears quite different between images. Pancreatic debris accounts for the additional tissue observed in (b) prior to final cleaning

recommended [86], with $11 \mathrm{~mL}$ RPMI 1640 complete media in each dish.

An optimal density of four islets per square centimeter has been suggested to prevent competition for nutrients [66]. Using the standard $100 \mathrm{~mm} \times 20 \mathrm{~mm}$ culture dish with $\sim 55 \mathrm{~cm}^{2}$, this allows for $\sim 220$ islets per culture dish. Our lab prepares three culture plates per mouse, one for the islets immediately post separation, one plate for the initial hand cleaning of the islets two to $4 \mathrm{~h}$ post separation, and the last plate for the final cleaning after overnight $(16-20 \mathrm{~h})$ recovery. The initial $2-4$-h recovery period allows for the islets to rest from the insult of collagenase digestion and to begin recovery. Cleaning the islets from the acinar tissue and any dead or dying islets increases the chance of islet survival. The second cleaning the following morning should result in a pure islet culture with little or no acinar tissue. Each of these time points are shown in Fig. 5. Islets immediately post separation (Fig. 5a) have some acinar tissue still evident on the islets. The same islets are shown in Fig. 5b after a two-hour recovery period and initial hand cleaning. Figure $5 \mathrm{c}$ shows the same islets after overnight recovery and hand picking a final time. Note there is still some acinar tissue present in the final image.

To maintain optimal islet health and function, storage in a sterile incubator at $37{ }^{\circ} \mathrm{C}$ with $5 \% \mathrm{CO}_{2}$ and a humidified atmosphere is necessary [86]. Rodent islets can maintain glucose sensitivity for at least 1 week in culture with frequent media changes [86] and perhaps even longer based on data from human islets [86, 91]. It should be noted, however, that changes in rodent islet function can occur in as little as one to 4 days in culture [92].

Dispersion of Islets into Islet Cells Although the intact islet provides an excellent model system for studying the function of this pancreatic micro-organ, some experimental approaches require dispersion of islets into individual islet cell cultures. Examining subtypes of islet cells requires islet dispersion as a requisite step. Thus, islet dispersion allows for the separation and examination of islet subpopulations such as alpha, beta, delta, and other islet cell types. Further, dispersion provides a convenient model of the isolated beta cell by preventing gap junction coupling [93, 94], blocking calcium waves between cells [95], and reducing 


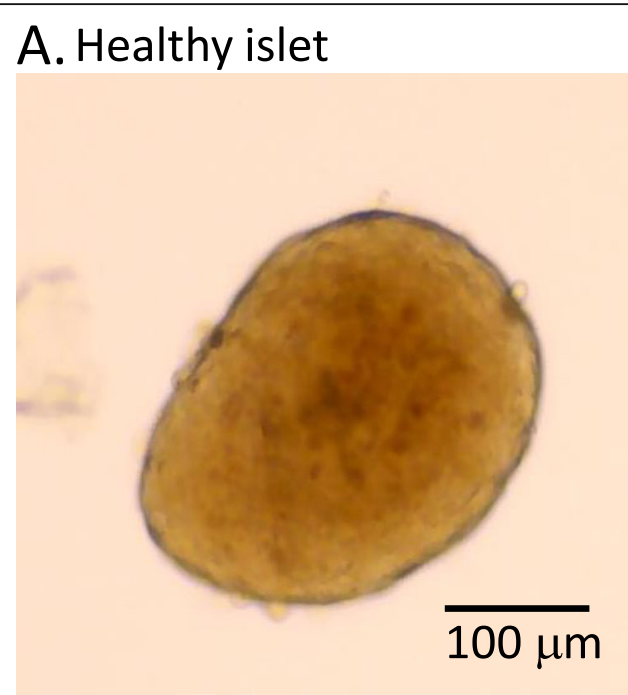

B. Attached acinar tissue

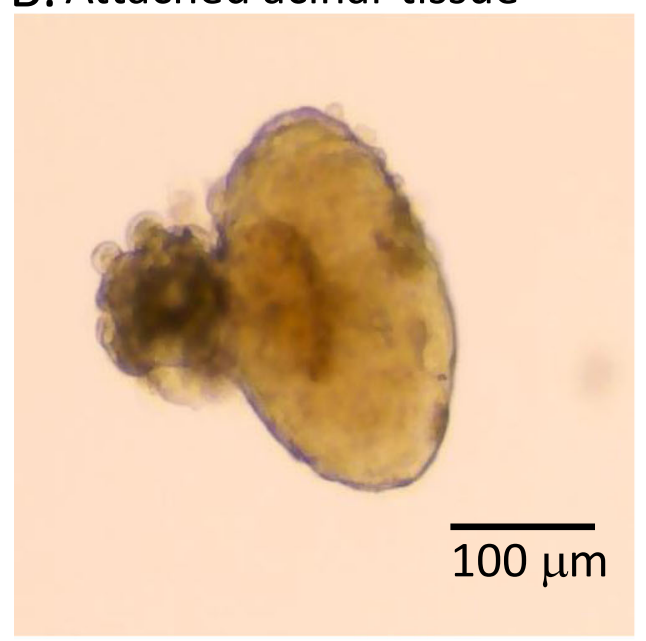

C. Necrotic Center

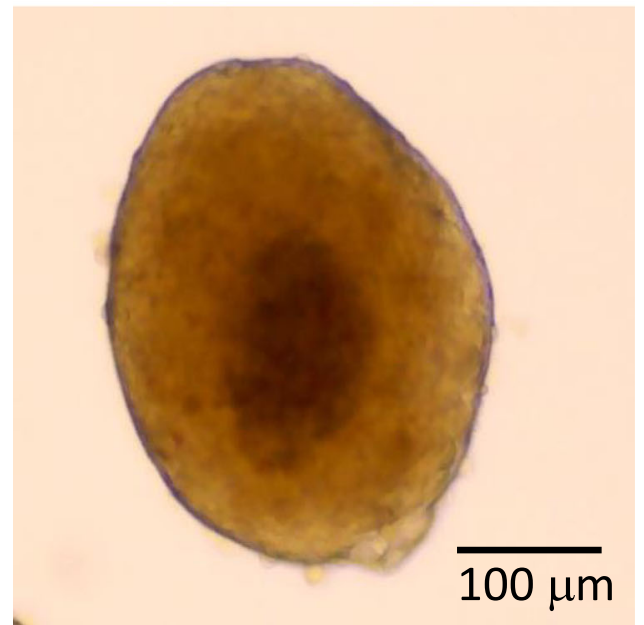

Fig. 6 Islets found in a typical preparation. a Example of a healthy islet with amber color. $\mathbf{b}$ Example of an islet with acinar tissue, which typically appears as dark brown or black tissue on the exterior of the islet. c Example of an islet with a necrotic core due to hypoxia

paracrine signaling $[96,97]$. This allows for comparisons between intact islets and dispersed beta cells [98]. A detailed protocol for dispersing, culturing, and identifying islet cells in culture is described in in Scarl \& Koch et al. [99].

\section{Assessing Islet Health and Function}

Once islets have been isolated and placed in culture, their health and function need to be assessed. In this section, we have updated and expanded the original description of assessment techniques presented in Carter et al [13].

\section{Morphology}

Rudimentary information regarding the health of an islet may be provided by visual inspection. When viewed under a light microscope with $4 \mathrm{x}$ magnification, healthy rodent islets appear spherical and golden-brown in color, with an approximate diameter of $50-250 \mu \mathrm{m}$. These features, particularly the color when compared to the exocrine tissue, allow for rapid identification of islets. Healthy isolated islets following overnight recovery have few, if any, individual cells protruding from their relatively smooth surface, such as the islet in Fig. 6a. Cells protruding from the surface of an islet (Fig. 6b) can be a sign of decreased or decreasing health, as is acinar tissue clinging to the exterior of an islet (Fig. 6b). Larger islets are also prone to developing hypoxic cells in their core, visibly distinguished as a darker region when compared to the surrounding area (Fig. 6c). It has been suggested that hypoxia can be reduced by culturing islets at a lower incubation temperature initially [100] or by reducing the volume of media in the culture dish to increase oxygenation [101].

\section{Viability}

To provide more quantitative measures of islet health than visual inspection alone, several techniques can be used to assess islet viability. We define viability as living versus dead or dying cells as assessed using cell exclusion or DNA-binding dyes. A common approach that is widely used in the human islet transplant field is to estimate the ratio of healthy living cells to dead cells within each islet by fluorescence microscopy. Fluorescein diacetate (FDA) incorporates into healthy cells by facilitated diffusion and fluoresces blue, and propidium iodide (PI) is a membrane impermeant red fluorescent dye that is excluded from viable cells and enters only dead or dying cells [102]. Using these fluorescent dyes in combination, the health of islets can be assessed by the FDA/PI ratio. 
Unmanipulated islets isolated from healthy control animals generally have 90-95\% viability, meaning blue FDA staining in $90-95 \%$ of the component cells of an islet and red PI staining in only $5-10 \%$ of the cells in an islet. Additional techniques include AnnexinV (AnnV), SYTO-13/ ethidium bromide, calcein AM/ethidium homodimer, fluorescein diacetate, and ethidium bromide [102-104].

Rodent islets in a good preparation are uniformly viable at $>95 \%$, so we primarily focus on quantifying cell death only. We use a variation of the above approach by quantifying the mean intensity of AnnV fluorescence to measure apoptosis and PI fluorescence to measure generalized cell death within an islet (see Appendix C). A region of interest is drawn around the perimeter of each islet using imaging software (CellSens, Olympus, USA) to quantify the fluorescent intensity of cell death signal per unit of crosssectional area for each islet. Figure 7 provides an example of typical staining patterns for cell death following overnight culture in normal conditions (6A, top), ER-stress inducer thapsigargin (6A, middle), and proinflammatory cytokines (6A, bottom). As shown in Fig. 7b, almost no AnnV staining was observed in controls (top), whereas substantial AnnV staining was observed in the other conditions. In Fig. 7c, virtually no fluorescence is detected in control islets (top), and only one region on one islet from the thapsigargin-treated group showed any PI staining (middle). In contrast, PI staining was extensive among cytokine-treated islets (Fig. 7c, bottom). These observations are consistent with established apoptosis-specific pathways of thapsigargin-induced cell death [105] versus apoptotic and necrotic pathways activated by cytokines $[106,107]$. We have published this approach previously to measure islet cell death in response to proinflammatory cytokines $[108,109]$ and high concentrations of metformin [110]. It should be noted that isolated islets, having lost vascular connection, can become severely hypoxic. This results in necrosis, especially in the core of the islet. Identification and removal of these islets from experiments can help in acquiring more accurate experimental data (see Supplemental Fig. S1 for additional details).
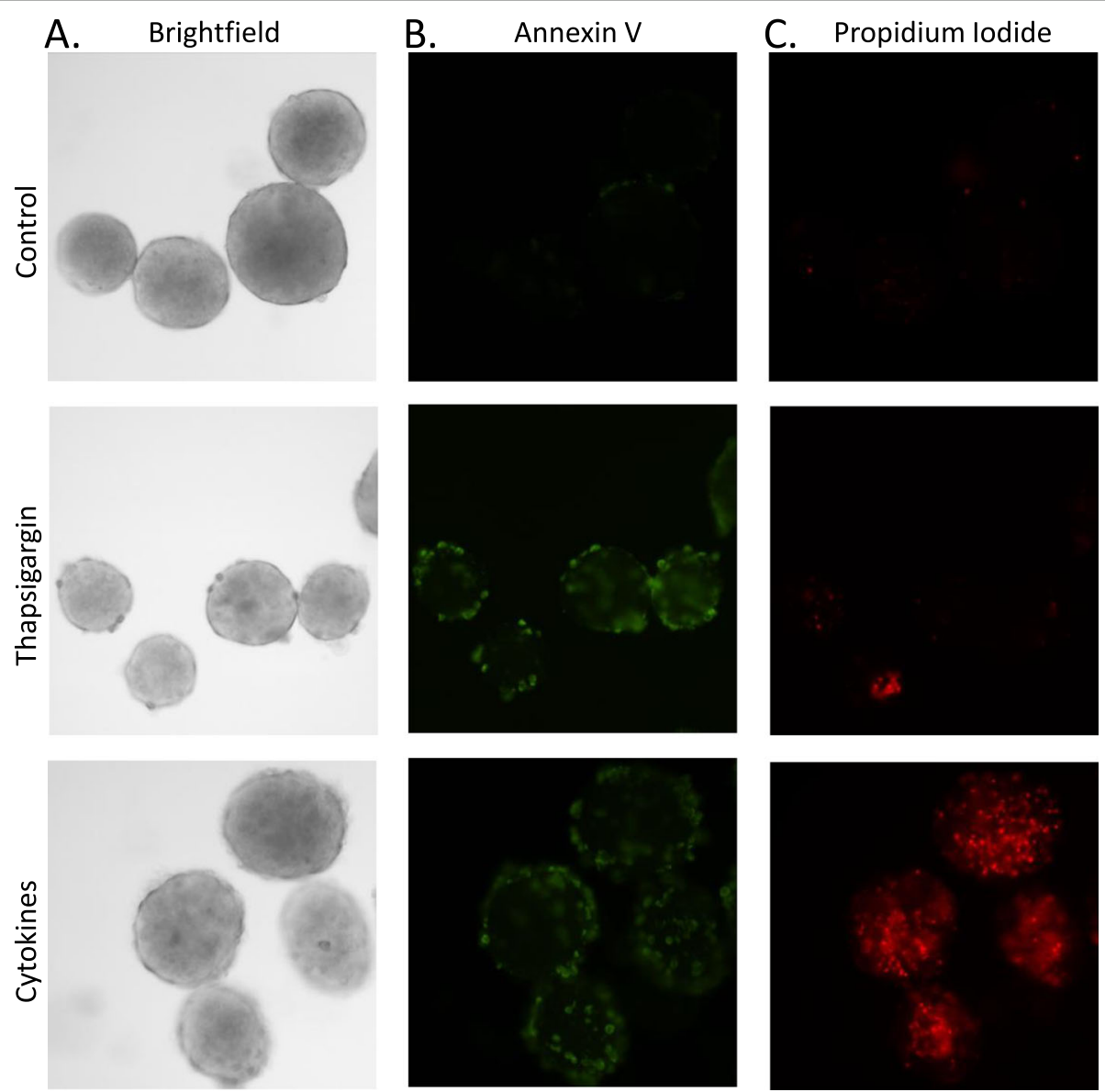

Fig. 7 An example of thapsigargin-induced and cytokine-induced cell death as measured by annexin $\mathrm{V}$ and propidium iodide fluorescence. a $\mathrm{A}$ brightfield image of healthy mouse islets (top), islets treated overnight with $100 \mathrm{nM}$ thapsigargin to induce ER stress (middle), and islets treated overnight with $5 \mathrm{ng} / \mathrm{mL}$ IL-1 beta and $10 \mathrm{ng} / \mathrm{mL}$ TNF-alpha (cytokines) to induce cell death (bottom). b Annexin $V$ is depicted with green fluorescence and propidium iodide is depicted with red fluorescence (c) 


\section{Glucose-Stimulated Insulin Secretion (GSIS)}

Insulin is crucial in regulating blood glucose, and reduced insulin secretion is a key feature of both type 1 and type 2 diabetes [111]. A fundamental property of islets is their capacity to regulate insulin release in direct response to changes in extracellular glucose concentrations. This ability defines islet function since insulin is produced and released only from islet beta-cells. There are other peptides produced by islet cells, such as glucagon, somatostatin, ghrelin, pancreatic polypeptide, as well as numerous "nonclassical" peptides [112]. These peptides are secreted in smaller amounts than insulin and are potentially more difficult to detect. Glucose-stimulated insulin secretion (GSIS) is thus a well-accepted measure of islet function and is considered the gold standard.
GSIS may be measured either by static conditions or by perfusing islets to measure the kinetics of insulin release in response to glucose. Each technique has its advantages and disadvantages which are reviewed elsewhere [113]. Typically, to measure functional GSIS, islets are cultured in a 'low' glucose concentration near $3 \mathrm{mM}$. This is to measure the amount of insulin secreted into the supernatant under 'basal' or 'unstimulated' conditions. Stimulated insulin release is then measured by exposing the islets to a higher glucose concentration such as $11 \mathrm{mM}$ (half-maximal) or $>20 \mathrm{mM}$ (maximal). In response to glucose stimulation, the time course of the islet response is biphasic, with a rapid spike in insulin (first phase) followed by a decline to a prolonged plateau (second phase) that remains for the duration of
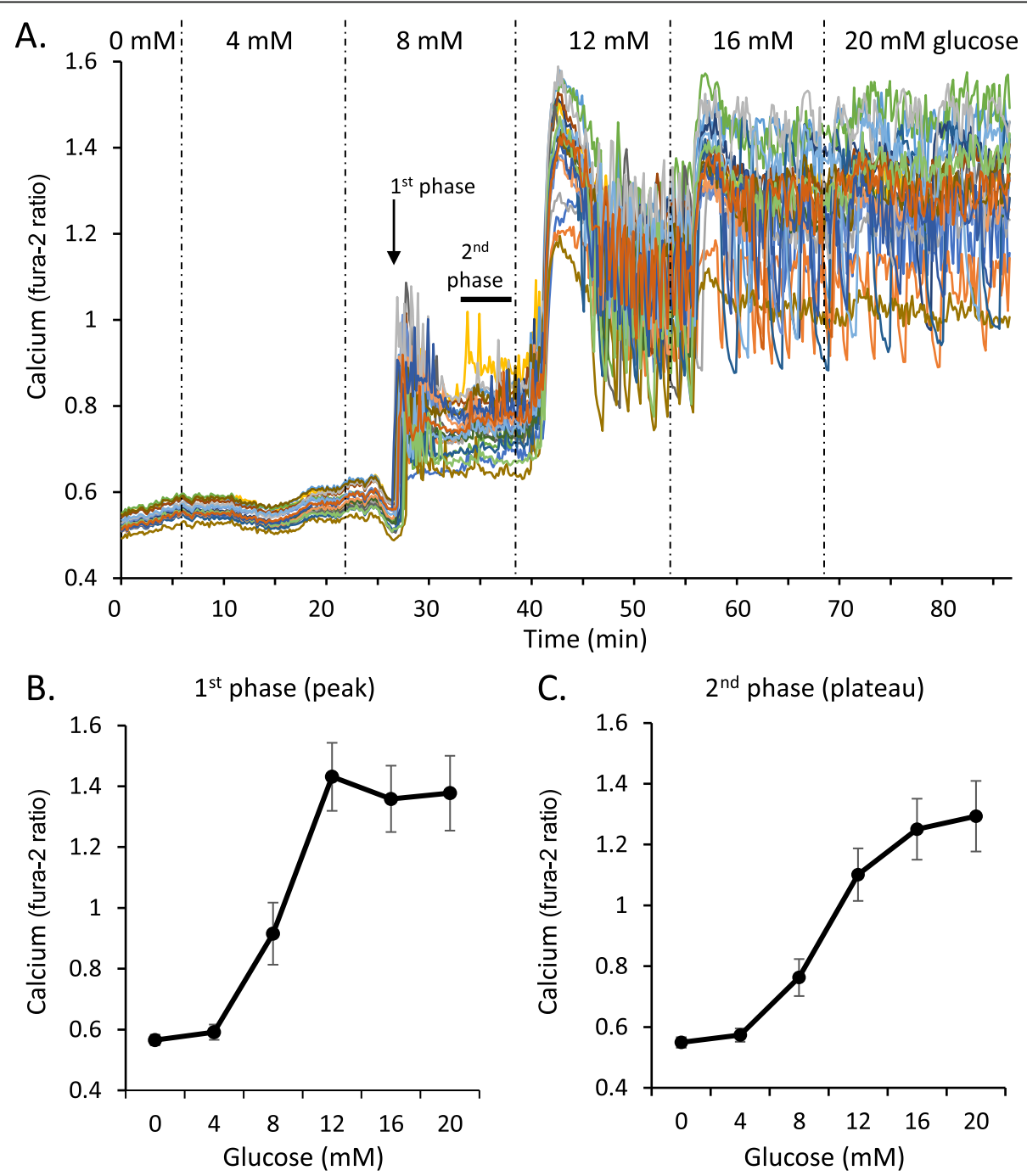

Fig. 8 Calcium response to glucose stimulation. a Calcium traces recorded at 10-s intervals during a series of increasing glucose steps $(0,4,8,12$, $16,20 \mathrm{mM}$ ) in an 90-min recording ( $N=20$ islets). For each glucose step both 1st phase (peak) and 2nd phase (plateau, measured in the last 5min) were measured. b-c Mean values for each phase at each glucose step are used to assemble glucose dose-response curves for 1st phase (b) and 2 nd phase (c) calcium responses as an indicator of islet function 
the stimulus. These are used to obtain a stimulation index (SI), the ratio of stimulated-to-basal insulin secretion. Healthy islets have an SI of 2-20 depending on several factors including strain, age, body weight, and glucose concentrations selected [82, 90].

One of the drawbacks to GSIS is the large number of islets required to conduct a thorough assessment. In recent years, the development of micro-plate assays using one islet per well have been used in an attempt to reduce the number of islets required for assessment, especially with regard to human islet transplantation [114]. Another point of contention is how best to control for variations in insulin secretion amongst islets to present the data obtained from a GSIS assay. In Slepchenko et al, we compared several normalization processes including total protein, insulin content, and islet area [115]. We concluded that normalization is not helpful in most cases as long as islets are within a size range of approximately $+/-50 \%$ of the mean because insulin secretion appears to be generally independent of islet size [115]. Among the normalization methods available, measuring the cross-sectional islet area was optimal for normalizing insulin secretion [115].

\section{Intracellular Calcium Imaging}

Another important method to assess islet function is measuring changes in intracellular calcium $\left(\left[\mathrm{Ca}^{2+}\right]_{\mathrm{i}}\right)$ in response to glucose or other stimuli [116]. We have used the ratiometric probe Fura-2 AM with an epifluorescent microscope [98], but there are many other calcium probes with different excitation and emission spectra that are capable of detecting changes in $\left[\mathrm{Ca}^{2+}\right]_{\mathrm{i}}$ including fluo-3, fluo-4, and fura red. Improved versions of some of these fluorophores have reduced leakage and photobleaching [117, 118]. Transfectable probes that target specific calcium-containing organelles such as the endoplasmic reticulum and mitochondria are also available $[119,120]$. These more sophisticated probes require Forrester resonance energy transfer (FRET).

We and others have found that Fura-2 AM can provide a basic picture of islet function and dysfunction [121-123]. As shown in Fig. 8a, changes in $\left[\mathrm{Ca}^{2+}\right]_{\mathrm{i}}$ can be assessed across multiple glucose steps to provide a detailed view of dose-dependent glucose stimulation. The 0 and $4 \mathrm{mM}$ glucose concentrations are subthreshold, so there is little change in $\left[\mathrm{Ca}^{2+}\right]_{i}$ activity as measured by the ratio of fluorescence intensity from 340/ $380 \mathrm{~nm}$ excitation light. The step to $8 \mathrm{mM}$ glucose produces a classic biphasic response: an initial first phase peak followed by a second phase plateau (Fig. 8a). The $12 \mathrm{mM}$ step provides the maximum first phase response in this example set of islets. The $\left[\mathrm{Ca}^{2+}\right]_{\mathrm{i}}$ levels continue to rise with each glucose step to maximum stimulation

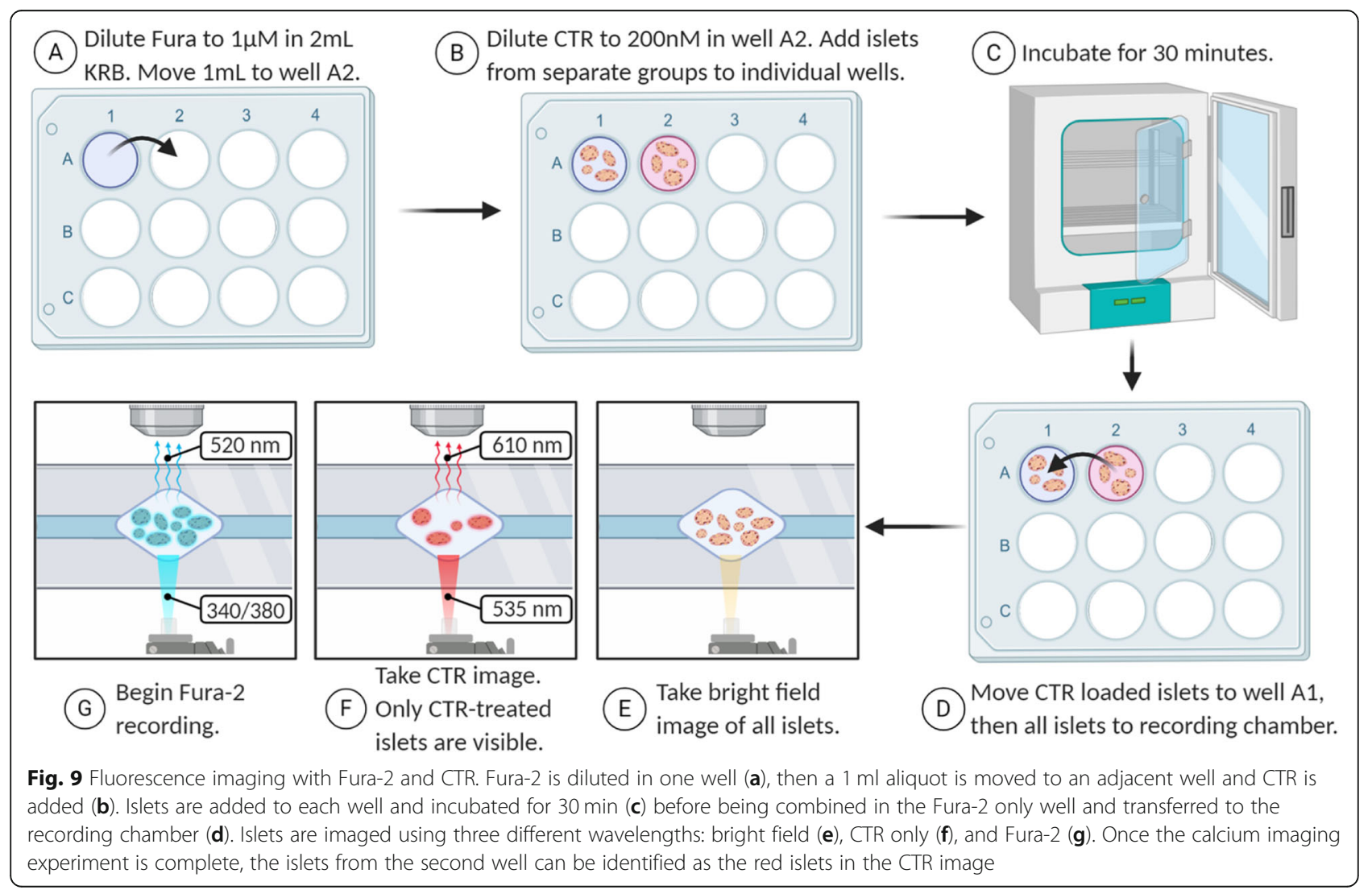


in $20 \mathrm{mM}$ glucose. This 'one-shot' experiment provides enough data to produce a glucose dose-response curve for both 1st phase (Fig. 8b) and 2nd phase (Fig. 8c) $\left[\mathrm{Ca}^{2+}\right]_{\mathrm{i}}$. The procedures we used for $\left[\mathrm{Ca}^{2+}\right]_{\mathrm{i}}$ imaging can be found in Scarl \& Koch et al. [99].

\section{The Use of Fluorescent Labels in $\left[\mathrm{Ca}^{2+}\right]_{\mathrm{i}}$ Experiments}

To extend the value of $\left[\mathrm{Ca}^{2+}\right]_{i}$ imaging as an evaluation tool of islet function, we utilize Cell Tracker Red (CTR) as a means to record and compare test groups side-byside with control groups of islets. The basic approach was first described by Corbin et al. [124] and is shown in cartoon form in Fig. 9. Briefly, Fura-2 is diluted in one well of a 12-well plate (A), half of the solution is moved to an adjacent well, and CTR is added to the second well (B). Untreated or control islets are added to the first well while the 'test islets' (e.g. islets from a mutant mouse, islets treated with drugs to stimulate or inhibit insulin secretion, islets put under stress, etc.) are added to the second well and incubated for $30 \mathrm{~min}(\mathrm{C})$. At the end of the 30-min incubation (dye loading period) the islets are briefly combined in the Fura-2 only well (D) and then transferred to the recording chamber of the microscope. It should be noted that this will introduce a very small amount of CTR into the Fura- 2 only well. This concentration is both extremely small and transient for the Fura- 2 only islets since the fluid flow of the chamber will wash excess CTR and Fura-2 away. Islets are then located and imaged using brightfield illumination $(E)$, then the red fluorescence is imaged from the CTR-labeled test cells only $(\mathrm{F})$, and the $\left[\mathrm{Ca}^{2+}\right]_{\mathrm{i}}$ signal from all islets is imaged (G). Data sets can be separated based on the red fluorescence image, with islets that are not visible belonging to the well 1 control and islets with red fluorescence belonging to the well 2 test condition.

This CTR-labeling approach is displayed in Fig. 10. Here we show brightfield (A), red fluorescence (B), and Fura-2 signal $(C)$ for sets of islets labelled with or without CTR. In Fig. 10d, we show $\left[\mathrm{Ca}^{2+}\right]_{\mathrm{i}}$ traces from a set of islets that were isolated from a diabetic $\mathrm{db} / \mathrm{db}$ mouse
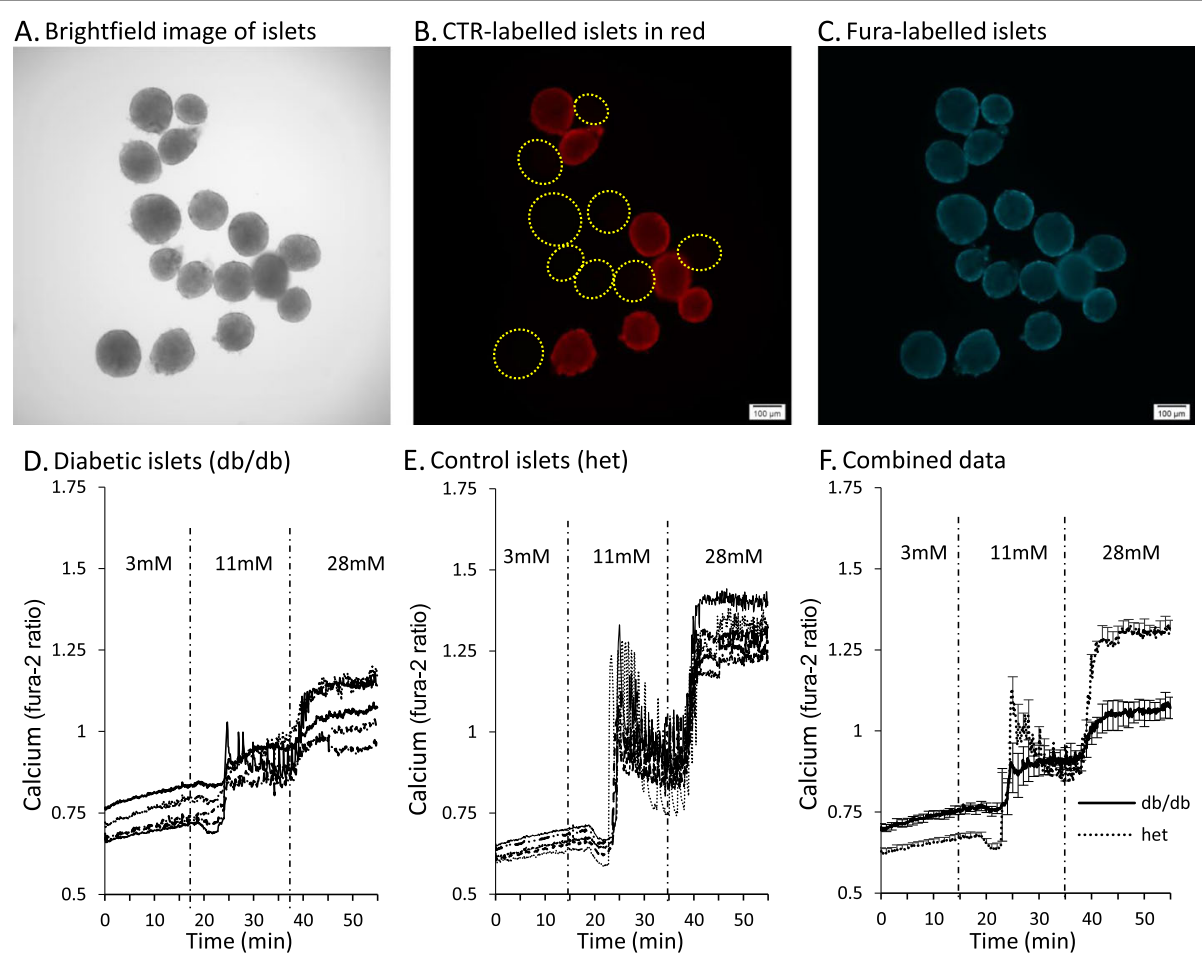

Fig. 10 Example of Cell Tracker Red (CTR) being used to identify two different treatment groups of islets. a-c Images of islets: group 1 contains control islets loaded with Fura-2 for 30 min, and group 2 contains "test" islets loaded with Fura-2 and 200 nM CTR for 30 min. Both groups of islets are combined in the recording chamber for live-cell fluorescence microscopy. a A brightfield image shows all islets (group 1 and group 2). b An image taken with filters to detect only red fluorescence light $(535 \mathrm{~nm} \mathrm{Ex;610} \mathrm{nm} \mathrm{Em).} \mathrm{Test} \mathrm{islets} \mathrm{(group} \mathrm{2)} \mathrm{produce} \mathrm{detectable} \mathrm{red}$ fluorescence due to the CTR label. Yellow circles surround the location of "invisible islets" from group 1 that were not labeled with CTR. c Fluorescence from the Fura-2 signal (380 nm Ex) is detectable in all islets, so that calcium recordings of group 1 and group 2 can be made simultaneously under identical experimental conditions. $\mathbf{d}$-f An example of a calcium recording using CTR to compare diabetic and healthy islets. d Calcium traces from diabetic islets isolated from db/db mice loaded with 1uM Fura- $2+200 \mathrm{nM}$ CTR for 30 min. e Calcium traces from healthy islets isolated from heterozygous control mice loaded with $1 \mathrm{uM}$ Fura-2 only. $\mathbf{f}$ Mean calcium traces for $\mathrm{db} / \mathrm{db}$ ( $N=5$ islets) and heterozygous controls $(\mathrm{N}=5)$ can be used to assess differences in amplitude, slope, and latency by directly comparing two treatment groups under identical environmental conditions 
and loaded with CTR and Fura-2. In Fig. 10e, we show $\left[\mathrm{Ca}^{2+}\right]_{\mathrm{i}}$ traces from the heterozygous controls that were loaded with Fura-2 only. As shown in Fig. 10f, the average responses were quite different, but the $\mathrm{x}$ - and $\mathrm{y}$-axes accurately reflect the signal from both sets of islets. Recording control and test groups simultaneously controls for temperature, perifusion rate, and other variables, which allows us to identify subtle changes in islet function that are important when making statistical comparisons. Previous studies using this approach have identified signs of endoplasmic reticulum stress [109] and dissociations between insulin secretion and $\left[\mathrm{Ca}^{2+}\right]_{\mathrm{i}}[125]$ by examining the latency, amplitude, and slope of islet $\left[\mathrm{Ca}^{2+}\right]_{\mathrm{i}}$ responses to glucose stimulation. Although $\left[\mathrm{Ca}^{2+}\right]_{\mathrm{i}}$ can be a convenient and insightful indicator of islet health and function, it is important to also measure insulin secretion due to many facets of the insulin secretory pathway that are separate from changes in $\left[\mathrm{Ca}^{2+}\right]_{\mathrm{i}}[125-128]$.

\section{Conclusions}

As stated previously, islet isolation is an intricate process, but the ability to consistently procure viable and functional islets is crucial to effectively study the physiology and pathophysiology of islets. In this review, we have addressed the key factors to consider in both the isolation and assessment processes to obtain healthy islets. We provide a method of isolation developed by integrating the reports of many others in the research field with careful experimentation to optimize the islet isolation process for our laboratory. While this protocol provides a start for islet isolation, any procedure must be optimized to the capabilities of the laboratory and the specific goals of the study.

\section{Supplementary Information}

The online version contains supplementary material available at https://doi. org/10.1186/s12575-021-00143-x.

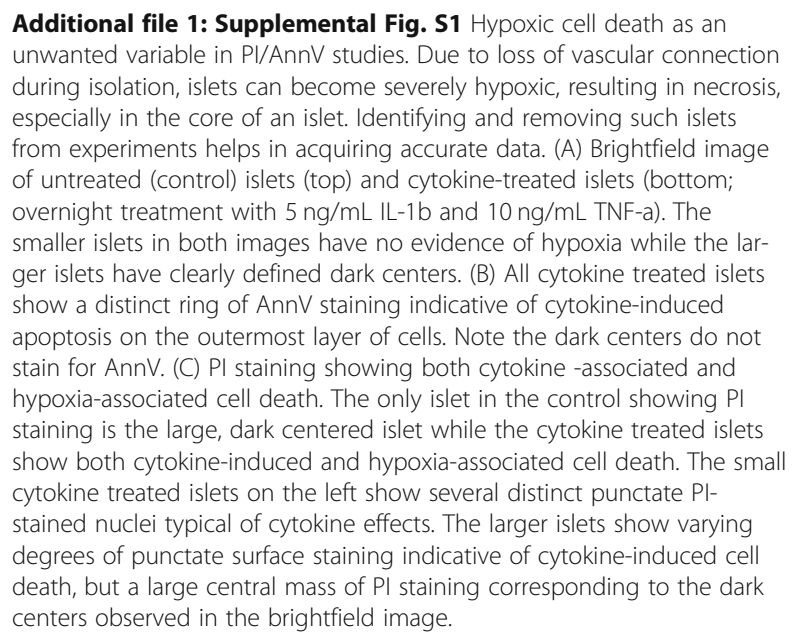

\section{Appendix A: An Annotated Protocol for the Isolation of Islets from Mice \\ Materials}

1 Forceps.

1 Fine dissecting forceps.

1 Fine Iris scissors for internal use.

1 standard pattern scissors.

1-2 Bulldog clamp(s).

30 or $27 \mathrm{G} 1 \frac{1}{2}$ " needle.

$5 \mathrm{~mL}$ Luer-lock syringe.

$25 \mathrm{~mL}$ pipette.

$10 \mathrm{~mL}$ pipette (1 per genotype/strain/sex/condition).

$5 \mathrm{~mL}$ pipette.

$15 \mathrm{~mL}$ conical tube (1 per mouse).

$50 \mathrm{~mL}$ conical tube (2 per mouse).

$2 " \times 2 "$ gauze.

$37^{\circ} \mathrm{C}$ water bath.

Scale (accurately measures in $\mathrm{mg}$ ).

Centrifuge.

Solutions.

For Anesthesia:

$\mathrm{CO} 2$ gas.

Or:

Solution (A): Mix $2 \mathrm{~mL}$ of ketamine and $1 \mathrm{~mL}$ of xylazine.

The concentration of xylazine used is $20 \mathrm{mg} / \mathrm{mL}$.

Solution (B): Mix (A) and $7 \mathrm{~mL}$ of Normal Saline, inj.

Various methods of anesthesia are used to ensure that research protocols follow humane methods. The following are used by our laboratory: $\mathrm{CO}_{2}$ gas for euthanasia, or Ketamine/Xylazine for IP injection. The dosage of ketamine/xylazine used to induce anesthesia is typically $0.005 \mathrm{~mL}$ per gram of body weight. Euthanasia is induced by doubling this volume. (A $20 \mathrm{~g}$ mouse would receive 0.1 $\mathrm{ml}$ of drug for anesthesia, $0.2 \mathrm{ml}$ for euthanasia).

For Islet Isolation:

G-Solution STERILE FILTERED in $0.22 \mu \mathrm{m}$ filter:

HBSS (Invitrogen \#14065-056 diluted to 1X).

$0.35 \mathrm{~g} \mathrm{NaHCO}_{3} / \mathrm{L}$.

1\% Bovine Serum Albumin (BSA).

This solution, as with any cell culture solution, must be sterile filtered. This method is performed using clean techniques, not sterile techniques; therefore, it is vital that the solutions are sterile prior to use.

Other protocols use protease inhibitors or varying concentrations of BSA to inactivate endogenous proteases, some as high as $10 \%$ BSA.

Prepare $100 \mathrm{~mL}$ G-solution per mouse.

Collagenase Solution:

Solution (C): $1.4 \mathrm{mg} / \mathrm{mL}$ Collagenase-P (Roche \#1129 002001) in G-Solution (prepare $5 \mathrm{~mL} /$ pancreas).

Collagenase is an area where there are differences in protocols. We have chosen to maintain a constant concentration of $1.4 \mathrm{mg} / \mathrm{mL}$ and to vary the digestion time to 
suit different lot numbers. Studies use different collagenase types, but we ensure specific criteria are met by each lot prior to use. The digestion time is based on islet function and viability experiments before using a new enzyme lot experimentally.

Gradient:

Histopaque 1100 Solution $(1.100 \mathrm{~g} / \mathrm{mL})$ :

$100 \mathrm{~mL}$ Histopaque 1077 (SIGMA \#10771).

$120 \mathrm{~mL}$ Histopaque 1119 (SIGMA \#11191).

We prepare and store a stock solution at $4{ }^{\circ} \mathrm{C}$. Only the amount of Histopaque required is brought to room temperature prior to its use. It is also important to note that the Histopaque solutions should be kept in the dark. Culture Media:

RPMI 1640 +L-Glutamine (Gibco \#11875-093). 10\% FBS (Gibco \#16000-044).

Penicillin $\quad(100 \mathrm{U} / \mathrm{mL}) /$ Streptomycin $\quad(100 \mu \mathrm{g} / \mathrm{mL})$ (Gibco \#15140-122).

\section{Protocol}

1. Label all tubes, vials, and plates clearly and prepare all required volumes of solutions as well. Add 10 $\mathrm{mL}$ culture media to cell culture plates and place in $5 \% \mathrm{CO} 2$ incubator set at $37^{\circ} \mathrm{C}$ to warm.

2. Prepare $100 \mathrm{~mL} \mathrm{G}$-solution per mouse.

3. Place $25 \mathrm{~mL}$ of G-Solution into one set of the 50 $\mathrm{mL}$ conical tubes and set aside.

4. Prepare $1 \mathrm{~mL}$ of G-solution for each mouse in a 15 $\mathrm{mL}$ conical.

5. Place each $15 \mathrm{~mL}$ conical from Step 4 in ice. To inhibit the collagenase digestion prior to incubation, place a $15 \mathrm{~mL}$ conical containing 1 $m L$ of G-solution for each mouse on ice. The ice will maintain the collagenase-filled pancreata at a temperature which inhibits digestion. The ice also serves to maintain uniform conditions while isolating islets from multiple pancreata.

6. Make up $n+1$ volume of collagenase solution (Solution C) and place in ice with $15 \mathrm{~mL}$ conical tubes.

The $n+1$ adds a layer of protection should more collagenase solution be required, especially for those just learning to cannulate the common bile duct.

7. Euthanize animal with $\mathrm{CO}_{2} \mathrm{OR}$ inject mouse IP with $0.01 \mathrm{~mL} / \mathrm{g}$ body weight of Solution (B). The mouse is ready for exsanguination after no response to pinching its foot. NOTE: The investigator MUST refer to institution Animal Care and Use Committee guidelines and policies regarding proper procedures when handling and using animals in research.

Some researchers prefer to use ketamine/xylazine when collecting blood samples.
8. (Optional) Exsanguinate the animal by heart perfusion using a $1 \mathrm{~mL}$ syringe with $25 \mathrm{Ga}$ needle or using preferred method.

Do not remove or disrupt the liver as this will destroy the common bile duct and remove the possibility of cannulation.

9. Wet abdominal fur with $70 \%$ alcohol to reduce the chance of hair contamination in the IP cavity during subsequent steps.

10. Open abdomen with standard pattern scissors in a V-shape starting from the lower abdomen and extending to the lateral portions of the diaphragm in order to expose all organs in the peritoneal cavity.

11. Turn the animal so that the nose is closest to the surgeon and the tail points away from the surgeon. This position allows for cannulation into the common bile duct from the rostral end closest to the liver at the junction of the cystic and hepatic ducts, leaving space to inject again closer to the duodenum if an error occurs.

12. Secure the liver with $2 " \times 2 "$ gauze. Lay the liver flat and place an unfolded $2^{\prime \prime} \times 2$ " piece of gauze under the liver closest to the surgeon. The gauze may be stretched across the xiphoid process and gently pressed down. This will cause the liver to become prominent and easier to gently flip over onto the gauze, exposing the junction of the gall bladder and common bile duct. Fold the remaining gauze over the liver to secure it during cannulation of the common bile duct.

13. Using a Johns Hopkins Bulldog clamp (Roboz\# RS7441), clamp off the common bile duct (common bile duct) near the junction with the small intestine. Alternatively, tightly tied suture string can be used to tie off the common bile duct at the junction with the small intestine.

The pancreas contains a system of ducts that allows pancreatic enzymes to flow into the gut. The pancreatic duct merges with the inferior end of the common bile duct where the pancreatic enzymes enter the duodenum (see Fig. 3 ). This pancreatic duct provides the most readily available access to the endocrine pancreas. Clamp the common bile duct as close to the junction with the small intestine as possible so as not to occlude the pancreatic duct. Clamping the duodenum on either side of the junction with the common bile duct is also an option. Using a clamp allows access to the pancreatic duct while closing off access to the duodenum. Also attached to the common bile duct are several hepatic ducts. After becoming proficient with the perfusion technique, the major hepatic duct that leads to the caudal right lobe of the liver could 
also be clamped to ensure that minimal collagenase is delivered to the liver.

14. Fill a $5 \mathrm{~mL}$ syringe with Solution (C).

15. Cannulate the common bile duct with a 27-30gauge $1 / 2$ in needle secured to a $5 \mathrm{~mL}$ syringe OR a 27-30-gauge butterfly needle. Cannulate the common bile duct at the junction of the cystic duct from the gall bladder and left hepatic duct from the liver (forms a Y-shape, see Fig. 3).

Needle size is often dictated by the size of the mouse. The average B6 mouse usually requires a 30-gauge needle while larger mice, such as a $C D$ 1 will accommodate a 27-gauge needle. At the most superior portion of the common bile duct the junction of the cystic duct and hepatic duct forms a Y-shaped reference point in most mice. This location allows the surgeon the opportunity to cannulate the common bile duct with a 27gauge butterfly needle OR a 27-gauge $1 / 2$ in needle in $5 \mathrm{~mL}$ syringe. Tips for a successful cannulation of the duct: 1) use a new needle for each attempt because the needle may dull very easily; 2) place the needle at the Y-shaped junction and slide the needle into the duct moving in $1 \mathrm{~mm}$ increments (small-scale movement is the key to success); 3) if the duct is difficult to visualize, squeeze gently on the gall bladder which may cause the common bile duct to turn yellow as bile flows through.

16. Inject 3-5 $\mathrm{mL}$ of Solution (C) into common bile duct.

A. An injection of 3-5 mL collagenase solution into the common bile duct should be sufficient to completely inflate the pancreas such that there is fluid in all regions of the pancreas from head to tail. The volume will be dictated by the size of the pancreas, with large mice requiring larger volumes. Ensuring that the collagenase inflates the pancreas in its entirety allows for the maximum yield of islets. The distribution of islets in the pancreas is not uniform; studies show a higher concentration of islets in the pancreatic tail, which makes the full inflation of the pancreas even more important. This step requires skill of the surgeon to obtain consistent results, and success is directly related to islet yield.

B. Failed attempts to infuse the pancreas with collagenase through the hepatic duct eventually destroy the duct. An alternative method involves directly injecting collagenase into the numerous lobes of the pancreas. In this method, it is important to inject small amounts (about 1-2 drops) of collagenase into as many of the lobes of the pancreas as possible.

17. Remove pancreas from mouse and place into labelled $15 \mathrm{~mL}$ conical from Step 5 .
A. During the removal of the pancreas, it is important to avoid intestinal rupture to reduce the risk of contamination of the cell culture by intestinal bacteria. Removal begins at the point of attachment of the common bile duct to the duodenum. Using forceps or scissors snip the common bile duct and gently detach the pancreas from the intestines. Then, cut the common bile duct from the attachment to the liver. Continue to remove the pancreas from the greater curvature of the stomach and finally the spleen. Place the removed pancreas into the $15 \mathrm{~mL}$ conical that holds $1 \mathrm{~mL}$ of cold G-solution and replace the tube in the ice.

B. After injecting the pancreas, place the pancreas that has been directly injected with collagenase into $1 \mathrm{~mL}$ of collagenase solution on ice, rather than Gsolution, as in the preferred common bile ductcannulation method above.

18. Repeat the above steps for all mice, THEN proceed to the next step.

Follow the above procedure for the remaining animals placing one pancreas per tube on ice. Our lab recommends no more than six mice per isolation attempt.

19. Incubate for $8^{*} \mathrm{~min}$. at $37^{\circ} \mathrm{C}$ in $15 \mathrm{~mL}$ conical tube. "Incubation time varies among different lots of Collagenase (usually 7-10 min).

After collecting the pancreata into their respective tubes on ice, place the same tubes directly into a water bath at $37^{\circ} \mathrm{C}$ to incubate for 7-10 min. The incubation time varies between lots of collagenase; therefore, it is important to test each lot prior to use in experimental conditions.

20. Shake the $15 \mathrm{~mL}$ tube containing digested pancreas hard by hand for approximately $5 \mathrm{~s}$ to complete the separation of tissue (the result should be the consistency of pea soup and free of large pieces of pancreatic tissue if the pancreas was completely inflated).

This step results in the mechanical digestion of the pancreas and can be performed for all tubes simultaneously if the tubes are placed into a rack for incubation and covered while shaking. If fat tissue was incubated with the pancreas, it will remain undigested after shaking.

21. Quickly fill to $15 \mathrm{~mL}$ with G-solution to dilute collagenase concentration and slow the digestive process.

22. Centrifuge $2 \mathrm{~min}$ at $1200 \mathrm{rpm}$ (290xG).

23. Discard the supernatant by decanting into a waste container.

24. Wash with of $10 \mathrm{~mL}$ G-Solution, 2 min at $1200 \mathrm{rpm}$ (290xG). 
All wash steps, unless otherwise stated, involve resuspending the tissue pellet with a sterile 10-mL pipette using room temperature HBSS followed by room temperature centrifugation at $290 x \mathrm{G}$ for $2 \mathrm{~min}$.

25 . Discard the supernatant by decanting into a waste container.

26. Add $10 \mathrm{~mL}$ of $\mathrm{G}$ solution and resuspend with a 10 $\mathrm{mL}$ pipette.

27. Filter each sample through a size $40(420 \mu \mathrm{m})$ sieve (Bellco Glass, Inc., Cat\# 1985-00040) into separate $50 \mathrm{~mL}$ conical tubes.

It is important to put each pancreas into its own conical so that the gradient can sustain the tissue load and properly separate the islets from the exocrine tissue. Overloading the gradient will lead to reduced islet yield and purity.

28. Bring volume to $20 \mathrm{~mL}$ with G-solution.

29. Centrifuge at $1200 \mathrm{rpm}$ (290xG) for $2 \mathrm{~min}$ to pellet resuspended tissue.

30. Decant supernatant and place the opening of the $50 \mathrm{~mL}$ conical onto a paper towel to remove as much liquid as possible.

Removing all the liquid ensures that the gradient density is not diluted when the pellet is resuspended in the gradient.

31. Resuspend pellet in $15 \mathrm{~mL}$ Histopaque 1100 Solution with a $10 \mathrm{~mL}$ pipette.

Resuspending the tissue completely in the gradient ensures that islet density is not affected by attached exocrine tissue. Tissue filtered through the sieve should resuspend to a state that appears almost homogenous in the gradient.

32. Centrifuge for $20 \mathrm{~min}$ at $1200 \mathrm{rpm}$ (290xG). NOTE: ISLETS are in the SUPERNATANT. After centrifugation, islets should be visible in the supernatant of the gradient as floating white specks. If there are fewer islets present than expected, resuspend the pellet produced during the previous step in order to inspect for islets. Also note that if more than one pancreas is added to the gradient, many islets will be found in the pellet. This should not be the case if the gradient contains only one mouse pancreas.

33. Decant the supernatant into the $50 \mathrm{~mL}$ conical with $25 \mathrm{~mL}$ of G-solution set up in step 3.

---NOTE: Collect all washes below to be able to look through them later.---

34. Centrifuge at $1500 \mathrm{rpm}(453 \mathrm{xG})$ for $4 \mathrm{~min}$ and decant the supernatant. NOTE: ISLETS are in the PELLET.

Take care to pour the solution into the waste container in one motion to avoid having the solution wash back onto the pellet causing the islets to become dislodged and subsequently decanted.

35. Add $10 \mathrm{~mL}$ of G-solution to the pellet and pipette up and down several times with a $10 \mathrm{~mL}$ pipette. The final washes of the pellet are very important to ensuring that the islets are clear of the Histopaque solution and that the islets are well separated from one another prior to plating in culture dishes.

36. Centrifuge at $1200 \mathrm{rpm}$ (290xG) for $3 \mathrm{~min}$.

37. Decant the supernatant and replace with $5 \mathrm{~mL}$ of pre-warmed culture medium using a new, sterile 5 $\mathrm{mL}$ serological pipette.

RPMI1640 with 10\% FBS and 1\% Pen/Strep

38. Transfer to a sterile Petri dish under culture hood then place in incubator to recover for two hours before initial cleaning under a dissecting or light microscope.

Use a suspension (Petri) culture dish so that the islets do not stick as they would in a tissue-culture treated. Incubate or pick clean islets under dissecting or light microscope using low-retention pipette tips.

\section{Appendix B: Bullet Point Protocol for Mouse Islet Isolation and Purification}

Set up for dissection, scale, ruler, 2 forceps, 2 scissors, bulldog clamp, gauze, $1 \mathrm{~mL}$ and $5 \mathrm{~mL}$ syringes, and ice bucket.

Make sure water bath is on and set to $37^{\circ} \mathrm{C}$.

Label plates (3/mouse) and fill with RPMI (10 ml minimum). Place in $5 \% \mathrm{CO}_{2}$ incubator at $37^{\circ} \mathrm{C}$.

Label one $15 \mathrm{ml}$ and two $50 \mathrm{ml}$ conical tubes per mouse.

Label $50 \mathrm{ml}$ conical tube for Histopaque and add $15 \mathrm{ml}$ of Histopaque per mouse.

Make $100 \mathrm{~mL}$ G-solution/mouse (90 mL HBSS + 10 $\mathrm{mL}$ BSA per mouse) in an appropriately sized beaker.

$1 \mathrm{~mL}$ in each $15 \mathrm{~mL}$ conical and place on ice.

$25 \mathrm{~mL}$ in each empty $50 \mathrm{~mL}$ conical (1/mouse).

$5 \mathrm{~mL}$ (per mouse) + an extra $5 \mathrm{~mL}$ in the $50 \mathrm{~mL}$ beaker $(\mathrm{n}+1)$.

Place remaining G-solution with a $25 \mathrm{~mL}$ pipet near the centrifuge along with the $50 \mathrm{~mL}$ tube rack and waste bucket.

Make $5 \mathrm{~mL}$ collagenase solution/mouse (plus an extra $5 \mathrm{~mL}$ ) add $7 \mathrm{mg} /$ mouse of collagenase $P$ to the $5 \mathrm{~mL} /$ mouse of G-solution in the $50 \mathrm{~mL}$ beaker $\left((\mathrm{n}+1)^{*} 7\right)$.

Euthanize mouse per lab protocol.

Wet fur with alcohol, cut open abdomen up to forelegs, and turn animal with head closest to you. Pin rear feet if needed.

Pinch the end of one strip of gauze between thumb and index fingers and press on xyphoid process, scooping down and under the liver until it pops up. Fold the 
other end of the gauze over the liver to pin it down and expose the common bile duct.

Use Bulldog clamp to pinch white dot (ampulla of Vater) on small intestine, then lay clamp on the intestines on the left side.

Cannulate the common bile duct with collagenase solution. Longer bezel edge down, inject 4-5 $\mathrm{mL}$ or remove and pocket inject.

Remove pancreas and place in $15 \mathrm{~mL}$ conical.

Repeat steps 8-13 for all mice.

Purification Protocol:

"Pre-heat water bath".

1. Digest @ $37^{\circ}$ for 8 min.

2. Shake well to aid digestion.

3. Add G-solution to $15 \mathrm{~mL}$ mark.

Spin @1200 for 2 min.

4. Pour off supernatant, add $10 \mathrm{~mL}$ G-solution, resuspend. Spin @1200 for 2 min.

5 . Wet mesh to facilitate suspension flow.

6. Pour off supernatant, add $10 \mathrm{~mL}$ G-solution, resuspend/filter through metal mesh.

Add G-solution to $20 \mathrm{~mL}$.

Spin @1200 for 2 min.

7. Pour off supernatant, tamp on towel.

Add $15 \mathrm{~mL}$ Histopaque 1100, resuspend.

Spin @1200 for 20 min.

8. Keep supernatant - pour into $50 \mathrm{~mL}$ tubes w/ 25

$\mathrm{mL}$ G-solution (discard pellet).

Spin @1500 for $\mathbf{4}$ min.

9. Pour off supernatant, add $10 \mathrm{~mL}$ G-solution, resuspend.

Spin @1200 for $\mathbf{3}$ min.

10. Pour off supernatant, resuspend with $10 \mathrm{~mL}$ warm RPMI and plate.

\section{Appendix C: Cell Death Fluorescent Imaging Protocol}

1. Using a peristaltic pump, rinse the tubing by passing $\mathrm{dH}_{2} \mathrm{O}$ through an inline heater set at $37^{\circ} \mathrm{C}$ into a diamond bath imaging chamber mounted to a stage adaptor on a BX51WIF fluorescence microscope with a 10x objective.

2. Next, in a 12-well plate, prepare combined Propidium Iodide (PI) and Annexin V (AnnV) dye using desired glucose solution (our lab uses a $3 \mathrm{mM}$ glucose solution). PI, a cell exclusion dye, is used to detect generalized cell death. Apoptosis is measured using AnnV, which detect phospatidylserine when it is exposed to the outer leaflet of the plasma membrane during apoptosis.

a. Propidium iodide (MilliporeSigma, MA) dye solution is prepared by adding $7 \mathrm{ml}$ of $3 \mathrm{mM}$ stock PI solution to $700 \mathrm{ml}$ of $3 \mathrm{mM}$ glucose solution making a $30 \mathrm{mM}$ final working concentration.

b. Annexing $\mathrm{V}$ fluorescent dye (Invitrogen, $\mathrm{CA}$ ) is prepared by adding $35 \mathrm{ml}$ of stock AnnV conjugate to $700 \mathrm{ml}$ of $3 \mathrm{mM}$ glucose solution.

c. Both PI and AnnV dye solution can be prepared in the same well as both dyes have different fluorescent wavelengths $(700 \mathrm{ml}$ glucose solution $+7 \mathrm{ml} \mathrm{PI}+35 \mathrm{ml} \mathrm{AnnV}$ ).

3. Place the plate in a $37^{\circ} \mathrm{C}$ humidified atmosphere containing $5 \% \mathrm{CO}_{2}$. Cover plate with aluminum foil to block out light, making certain sides are covered as well.

4. In the warmed 12-well plate, add 20-25 islets to the $\mathrm{PI} / \mathrm{AnnV}$ prepared well. Replace plate into $37^{\circ} \mathrm{C}$ humidified atmosphere containing $5 \% \mathrm{CO}_{2}$ for $15 \mathrm{~min}$.

5. While islets are incubating, change the peristaltic pump so that it is passing $3 \mathrm{mM}$ glucose solution through the inline heater into the diamond bath imaging chamber rather than $\mathrm{dH}_{2} \mathrm{O}$.

6. After $15 \mathrm{~min}$ incubation, place the islets into the diamond bath imaging chamber mounted on the microscope.

7. Stained islets are images using a Hamamatsu ORCA-Flash 4.0 digital camera mounted to $\mathrm{s}$ BX51WIF fluorescence microscope.

8. Excitation is provided using a xenon burner supplied to the image field through a light pipe and filter wheel with a Lambda 10-3 Optical Controller.

9. Regions of interest (ROI) are drawn around each islet and a brightfield (BF) image is taken. The white light source for the microscope is then turned off.

10. Using cellSens Dimension 1.13 imaging software, fluorescent images are taken with $488 \mathrm{~nm}$ excitation/ $525 \mathrm{~nm}$ emission for Annexin V (GFP, green fluorescence) and $535 \mathrm{~nm}$ excitation $/ 620 \mathrm{~nm}$ emission for Propidium iodide (TRITC, red fluorescence).

a. Note islets with dense centers seen on the brightfield image denote hypoxic cores. Islets with hypoxic cores should be excluded from cell death analyses as they may represent false positives unrelated to treatment (see Fig. S1).

11. Repeat steps 4 through 10 for each treatment group. PI/AnnV fluorescent dye solution can be reused up to 4 incubation and measurements. Make fresh PI/AnnV solution for additional measurements.

When finished with all experiments, pass $\mathrm{dH}_{2} \mathrm{O}$ through tubing and chamber for 10 to $15 \mathrm{~min}$ to rinse out the system and shut down other equipment. Run air through tubing for an additional $10 \mathrm{~min}$ to dry tubing before shutting down peristaltic pump. 


\section{Abbreviations}

GSIS: Glucose-stimulated insulin secretion; AnnV: Annexin V; Pl: Propidium iodide; FDA: Fluorescein diacetate; $\left[\mathrm{Ca}^{2+}\right]_{\mathrm{i}}$ : Intracellular calcium; IL1 beta: Interleukin-1 beta; IL-6: Interleukin-6; TNF-alpha: Tumor necrosis factoralpha

\section{Acknowledgements}

A special thank you to Jeffrey D. Carter for the original inspiration to create a practical guide to rodent islet and assessment. Thanks to Dr. Guoqiang Gu at Vanderbilt University for his assistance and interest in this project and to Kira Slepchenko at Ohio University for her assistance and interest. Some figures created using BioRender.

\section{Authors' contributions}

CSN initiated the writing of this manuscript. WJK helped with writing several sections while HLW, NBW, and SB helped acquire data and performed data analysis. KLC wrote the majority of the manuscript with continual review and input from all contributors. All authors approved the final edition.

\section{Funding}

This work was funded by the NIDDK Mouse Metabolic Phenotyping Centers (National MMPC, RRID:SCR_008997, www.mmpc.org) under the MICROMouse Program, R15 DK121247 to CSN from the National Institute of Diabetes and Digestive Kidney Diseases (NIDDK), the Osteopathic Heritage Foundation $(\mathrm{OHF})$, and Ohio University Heritage College of Osteopathic Medicine (OU$\mathrm{HCOM}$.

\section{Availability of data and materials}

Not Applicable. This is a review article.

\section{Ethics approval and consent to participate}

No human subjects were involved. The Ohio University Animal Care and Use Committee approved the ethical use of animals involved in developing the methods reviewed in this manuscript (Protocol number: 15- $\mathrm{H}-021$ ).

\section{Consent for publication}

Not applicable.

\section{Competing interests}

The authors declare an absence of any commercial or financial relationships that could be construed as a potential conflict of interest.

\section{Author details}

${ }^{1}$ Heritage College of Osteopathic Medicine, Ohio University, Athens, OH, USA ${ }^{2}$ Department of Biomedical Sciences, Ohio University, Athens, OH, USA. ${ }^{3}$ Honors Tutorial College, Ohio University, Athens, OH, USA. ${ }^{4}$ Translational Biomedical Sciences Program, Graduate College, Ohio University, Athens, $\mathrm{OH}$ USA. ${ }^{5}$ Diabetes Institute, Ohio University, Athens, OH, USA.

\section{Received: 28 October 2020 Accepted: 26 January 2021}

\section{Published online: 01 March 2021}

\section{References}

1. Langerhans P, Morrison H. Contributions to the Microscopic Anatomy of the Pancreas. Bull Inst Hist Med. 1937;5(3):259-97.

2. Stylianou C, Kelnar C. The introduction of successful treatment of diabetes mellitus with insulin. J R Soc Med. 2009;102(7):298-303.

3. Volk BW, Arquilla ER. The diabetic pancreas. 2nd ed. Plenum Medical Book Company: New York and London; 1985.

4. Minkowski O. Historical development of the theory of pancreatic diabetes by Oscar Minkowski, 1929: introduction and translation by Rachmiel Levine. Diabetes. 1989;38(1):1-6.

5. Ramírez-Domínguez M. Historical Background of Pancreatic Islet Isolation. Adv Exp Med Biol. 2016;938:1-9.

6. Howard JM, Hess W. History of the Pancreas: Mysteries of a Hidden Organ. Boston. MA: Springer; 2002.

7. Bensley R. Studies on the pancreas of the guinea pig. Am J Anat. 1911;12(3): 297-387.

8. Hellerstroem C. A METHOD FOR THE MICRODISSECTION OF INTACT PANCRE ATIC ISLETS OF MAMMALS. Acta Endocrinol (Copenh). 1964;45:122-32.
9. Moskalewski S. ISOLATION AND CULTURE OF THE ISLETS OF LANGERHANS OF THE GUINEA PIG. Gen Comp Endocrinol. 1965;5:342-53.

10. Lacy PE, Kostianovsky M. Method for the isolation of intact islets of Langerhans from the rat pancreas. Diabetes. 1967;16(1):35-9.

11. Lindall A, Steffes M, Sorenson R. Immunoassayable insulin content of subcellular fractions of rat islets. Endocrinology. 1969;85(2):218-23.

12. Gotoh M, Maki T, Kiyoizumi T, Satomi S, Monaco AP. An improved method for isolation of mouse pancreatic islets. Transplantation. 1985;40(4):437-8.

13. Carter JD, Dula SB, Corbin KL, Wu R, Nunemaker CS. A Practical Guide to Rodent Islet Isolation and Assessment. Biol Proced Online. 2009;11:3-31.

14. Andrades P, Asiedu C, Ray P, Rodriguez C, Goodwin J, McCarn J, Thomas JM. Islet yield after different methods of pancreatic Liberase delivery. Transplant Proc. 2007;39(1):183-4.

15. Brandhorst $H$, Raemsch-Guenther N, Raemsch C, Friedrich O, Kurfuerst M, Korsgren O, Brandhorst D. Degraded collagenase deteriorates islet viability. Transplant Proc. 2008;40(2):370-1.

16. Stull ND, Breite A, McCarthy R, Tersey SA, Mirmira RG. Mouse islet of Langerhans isolation using a combination of purified collagenase and neutral protease. J Vis Exp. 2012;67. https://doi.org/10.3791/4137.

17. O'Dowd JF. The isolation and purification of rodent pancreatic islets of Langerhans. Methods Mol Biol Clifton NJ. 2009:560:37-42.

18. Hara Y, Taniguchi H, Ishihara K, Ejiri K, Tsutou A, Narutaki K, Baba S. Sophisticated mesh filtration technique of a large-scale isolation of islets and their function. Diabetes Res Clin Pract. 1989;6(2):103-8.

19. Mita A, Ricordi C, Messinger S, Miki A, Misawa R, Barker S, Molano RD, Haertter R, Khan A, Miyagawa S, Pileggi A, Inverardi L, Alejandro R, Hering $\mathrm{BJ}$, Ichii $\mathrm{H}$. Antiproinflammatory effects of iodixanol (OptiPrep)-based density gradient purification on human islet preparations. Cell Transplant. 2010; 19(12):1537-46.

20. Zongyi Y, Funian Z, Hao L, Ying C, Jialin Z, Baifeng L. A rapid, efficient, and economic device and method for the isolation and purification of mouse islet cells. PloS One. 2017:12(2):e0171618.

21. Salvalaggio PRO, Deng S, Ariyan CE, Millet I, Zawalich WS, Basadonna GP, Rothstein DM. Islet filtration: a simple and rapid new purification procedure that avoids ficoll and improves islet mass and function. Transplantation. 2002:74(6):877-9.

22. Ramírez-Domínguez M, Castaño L. Filtration is a time-efficient option to Histopaque, providing good-quality islets in mouse islet isolation. Cytotechnology. 2015;67(2):199-206.

23. Chan K-M, Raikwar SP, Zavazava N. Strategies for differentiating embryonic stem cells (ESC) into insulin-producing cells and development of noninvasive imaging techniques using bioluminescence. Immunol Res. 2007; 39(1-3):261-70.

24. Liang J, Ng KY, Cheng Q, Xia Y, Wang CC, Leung PS. Human fetal liver stromal cell co-culture enhances the differentiation of pancreatic progenitor cells into islet-like cell clusters. Stem Cell Rev Rep. 2014;10(2):280-94.

25. Kieffer TJ, Woltjen K, Osafune K, Yabe D, Inagaki N. Beta-cell replacement strategies for diabetes. J Diabetes Investig. 2017. https://doi.org/10.1111/jdi. 12758.

26. Lebreton F, Lavallard V, Bellofatto K, Bonnet R, Wassmer CH, Perez L, Kalandadze V, Follenzi A, Boulvain M, Kerr-Conte J, Goodman DJ, Bosco D, Berney T, Berishvili E. Insulin-producing organoids engineered from islet and amniotic epithelial cells to treat diabetes. Nat Commun. 2019:10(1):4491.

27. Petersson B. Isolation and characterization of different types of pancreatic islet cells in guinea-pigs. Acta Endocrinol (Copeh). 1966;53(3):480-8.

28. Ballinger WF, Lacy PE. Transplantation of intact pancreatic islets in rats. Surgery. 1972;72(2):175-86

29. Zmuda EJ, Powell CA, Hai T. A method for murine islet isolation and subcapsular kidney transplantation. J Vis Exp. 2011;50. https://doi.org/10. 3791/2096.

30. Neuman JC, Truchan NA, Joseph JW, Kimple ME. A method for mouse pancreatic islet isolation and intracellular CAMP determination. J Vis Exp. 2014;88:e50374

31. Mitok KA, Freiberger EC, Schueler KL, Rabaglia ME, Stapleton DS, Kwiecien NW, Malec PA, Hebert AS, Broman AT, Kennedy RT, Keller MP, Coon JJ, Attie AD. Islet proteomics reveals genetic variation in dopamine production resulting in altered insulin secretion. J Biol Chem. 2018;293(16):5860-77.

32. Hani H, Ibrahim TAT, Othman AM, Lila M-AM, bt Allaudin ZN. Isolation, density purification, and in vitro culture maintenance of functional caprine islets of Langerhans as an alternative islet source for diabetes study. Xenotransplantation. 2010;17(6):469-80. 
33. Zini E, Osto M, Franchini M, Guscetti F, Donath MY, Perren A, Heller RS, Linscheid P, Bouwman M, Ackermann M, Lutz TA, Reusch CE. Hyperglycaemia but not hyperlipidaemia causes beta cell dysfunction and beta cell loss in the domestic cat. Diabetologia. 2009;52(2):336-46.

34. Balamurugan AN, Ramakrishna B, Gunasekaran S. Insulin secretory characteristics of monkey pancreatic islets: a simple method of islet isolation and the effect of various density gradients on separation. Diabetes Res Clin Pract. 2004;66(1):13-21.

35. Andrades P, Asiedu CK, Gansuvd B, Inusah S, Goodwin KJ, Deckard LA, Jargal U, Thomas JM. Pancreatic islet isolation variables in non-human primates (rhesus macaques). Diabetologia. 2008;51(7):1236-44.

36. Lorenz D, Reding R, Petermann J, Beckert R, Worm V, Tietz W, Rosenbaum KD, Lippert H, Dorn A, Koch G. Transplantation of isolated islets of Langerhans into the liver of diabetic dogs (author's transl). Zentralbl Chir. 1976;101(22):1359-68.

37. Rosenberg L, Wang R, Paraskevas S, Maysinger D. Structural and functional changes resulting from islet isolation lead to islet cell death. Surgery. 1999; 126(2):393-8.

38. Saliba Y, Farès N. Isolation, Purification, and Culture of Mouse Pancreatic Islets of Langerhans. Methods Mol Biol Clifton NJ. 2019;1940:255-65.

39. Gotoh M, Ohzato H, Porter J, Maki T, Monaco AP. Crucial role of pancreatic ductal collagenase injection for isolation of pancreatic islets. Horm Metab Res Suppl Ser. 1990;25:10-6.

40. Shapiro AM, Hao E, Rajotte RV, Kneteman NM. High yield of rodent islets with intraductal collagenase and stationary digestion--a comparison with standard technique. Cell Transplant. 1996;5(6):631-8.

41. Li D-S, Yuan Y-H, Tu H-J, Liang Q-L, Dai L-J. A protocol for islet isolation from mouse pancreas. Nat Protoc. 2009;4(11):1649-52.

42. Bertera S, Balamurugan AN, Bottino R, He J, Trucco M. Increased yield and improved transplantation outcome of mouse islets with bovine serum albumin. J Transplant. 2012;2012:856386.

43. Atanes P, Ruz-Maldonado I, Olaniru OE, Persaud SJ. Assessing mouse islet function. Methods Mol Biol Clifton NJ. 2020;2128:241-68.

44. Sawada T, Matsumoto I, Nakano M, Kirchhof N, Sutherland DER, Hering BJ. Improved islet yield and function with ductal injection of University of Wisconsin solution before pancreas preservation. Transplantation. 2003; 75(12):1965-9.

45. Shimoda $M$, Itoh $T$, Sugimoto $K$, Iwahashi $S$, Takita $M$, Chujo D, Sorelle JA, Naziruddin B, Levy MF, Grayburn PA, Matsumoto S. Improvement of collagenase distribution with the ductal preservation for human islet isolation. Islets. 2012;4(2):130-7.

46. Gotoh M, Maki T, Satomi S, Porter J, Bonner-Weir S, O'Hara CJ, Monaco AP. Reproducible high yield of rat islets by stationary in vitro digestion following pancreatic ductal or portal venous collagenase injection. Transplantation. 1987;43(5):725-30.

47. Szot GL, Koudria P, Bluestone JA. Murine pancreatic islet isolation. J Vis Exp. 2007;7:255.

48. Do OH, Low JT, Thorn P. Lepr (db) mouse model of type 2 diabetes: pancreatic islet isolation and live-cell 2-photon imaging of intact islets. J Vis Exp. 2015;99:e52632.

49. Villarreal D, Pradhan G, Wu C-S, Allred CD, Guo S, Sun Y. A Simple High Efficiency Protocol for Pancreatic Islet Isolation from Mice. J Vis Exp. 2019; 150. https://doi.org/10.3791/57048.

50. Jennison MW. Bacterial Collagenase. J Bacteriol. 1945;50(3):369-70.

51. Harper E. Collagenases. Annu Rev Biochem. 1980;49:1063-78.

52. Gross J, Lapiere CM. Collagenolytic activity in amphibian tissues: a tissue culture assay. Proc Natl Acad Sci U S A. 1962;48:1014-22.

53. Woods JF, Nichols G. Distribution of collagenase in rat tissues. Nature. 1965; 208(5017):1325-6.

54. Mandl I, Maclennan JD, Howes EL. Isolation and characterization of proteinase and collagenase from Cl. histolyticum. J Clin Invest. 1953;32(12): 1323-9.

55. Bond MD, Van Wart HE. Characterization of the individual collagenases from Clostridium histolyticum. Biochemistry. 1984;23(13):3085-91.

56. Bond MD, Van Wart HE. Relationship between the individual collagenases of Clostridium histolyticum: evidence for evolution by gene duplication. Biochemistry. 1984;23(13):3092-9.

57. Grant NH, Alburn HE. Studies on the collagenases of Clostridium histolyticum. Arch Biochem Biophys. 1959;82(2):245-55.

58. Yoshida E, Noda H. Isolation and characterization of collagenases I and || from Clostridium histolyticum. Biochim Biophys Acta. 1965;105(3):562-74.
59. Kono T. Purification and partial characterization of collagenolytic enzymes from Clostridium histolyticum. Biochemistry. 1968;7(3):1106-14.

60. Harper E, Kang AH. Studies on the specificity of bacterial collagenase. Biochem Biophys Res Commun. 1970;41(2):482-7.

61. Lwebuga-Mukasa JS, Harper E, Taylor P. Collagenase enzymes from Clostridium: characterization of individual enzymes. Biochemistry. 1976: 15(21):4736-41

62. Fujio A, Murayama K, Yamagata $Y$, Watanabe $K$, Imura T, Inagaki A, Ohbayashi N, Shima H, Sekiguchi S, Fujimori K, Igarashi K, Ohuchi N, Satomi $\mathrm{S}$, Goto M. Collagenase $\mathrm{H}$ is crucial for isolation of rat pancreatic islets. Cell Transplant. 2014;23(10):1187-98.

63. Matsushita O, Jung CM, Katayama S, Minami J, Takahashi Y, Okabe A. Gene duplication and multiplicity of collagenases in Clostridium histolyticum. J Bacteriol. 1999;181(3):923-33.

64. Wolters $\mathrm{GH}$, Vos-Scheperkeuter $\mathrm{GH}$, van Deijnen $\mathrm{JH}$, van Schilfgaarde R. An analysis of the role of collagenase and protease in the enzymatic dissociation of the rat pancreas for islet isolation. Diabetologia. 1992;35(8):735-42.

65. Wolters GH, Vos-Scheperkeuter GH, Lin HC, van Schilfgaarde R. Different roles of class I and class II Clostridium histolyticum collagenase in rat pancreatic islet isolation. Diabetes. 1995;44(2):227-33.

66. de Haan BJ, Faas MM, Spijker H, van Willigen J-W, de Haan A, de Vos P. Factors influencing isolation of functional pancreatic rat islets. Pancreas. 2004;29(1):e15-22.

67. Brandhorst H, Friberg A, Andersson HH, Felldin M, Foss A, Salmela K, Lundgren T, Tibell A, Tufveson G, Korsgren O, Brandhorst D. The importance of tryptic-like activity in purified enzyme blends for efficient islet isolation. Transplantation. 2009;87(3):370-5.

68. Brandhorst D, Huettler S, Alt A, Raemsch-Guenther N, Kurfuerst M, Bretzel $\mathrm{RG}$, Brandhorst $\mathrm{H}$. Adjustment of the ratio between collagenase class $\|$ and I improves islet isolation outcome. Transplant Proc. 2005;37(8):3450-1.

69. Jahr H, Pfeiffer G, Hering BJ, Federlin K, Bretzel RG. Endotoxin-mediated activation of cytokine production in human PBMCs by collagenase and Ficoll. J Mol Med Berl Ger. 1999;77(1):118-20.

70. Caballero-Corbalán J, Friberg AS, Brandhorst H, Nilsson B, Andersson $\mathrm{HH}$ Felldin M, Foss A, Salmela K, Tibell A, Tufveson G, Korsgren O, Brandhorst D. Vitacyte collagenase HA: a novel enzyme blend for efficient human islet isolation. Transplantation. 2009;88(12):1400-2.

71. Brandhorst D, Brandhorst H, Johnson PRV. Enzyme Development for Human Islet Isolation: Five Decades of Progress or Stagnation? Rev Diabet Stud. 2017:14(1):22-38.

72. Qi M, Valiente L, McFadden B, Omori K, Bilbao S, Juan J, Rawson J, Scott S, Ferreri K, Mullen Y, El-Shahawy M, Dafoe D, Kandeel F, Al-Abdullah $I H$. The Choice of Enzyme for Human Pancreas Digestion is a Critical Factor for Increasing the Success of Islet Isolation. Transplant Direct. 2015;1(4). https:// doi.org/10.1097/TXD.0000000000000522.

73. Berney T, Molano RD, Cattan P, Pileggi A, Vizzardelli C, Oliver R, Ricordi C, Inverardi L. Endotoxin-mediated delayed islet graft function is associated with increased intra-islet cytokine production and islet cell apoptosis. Transplantation. 2001;71(1):125-32.

74. Vargas F, Vives-Pi M, Somoza N, Armengol P, Alcalde L, Martí M, Costa M, Serradell L, Dominguez O, Fernández-Llamazares J, Julian JF, Sanmartí A, Pujol-Borrell R. Endotoxin contamination may be responsible for the unexplained failure of human pancreatic islet transplantation. Transplantation. 1998;65(5):722-7.

75. Kessler $L$, Jesser $C$, Belcourt $A$, Pinget $M$. Influence of acinar tissue contamination on encapsulated pancreatic islets: morphological and functional studies. Transplantation. 1997;63(10):1537-40.

76. McCall MD, Maciver AH, Pawlick R, Edgar R, Shapiro AMJ. Histopaque provides optimal mouse islet purification kinetics: comparison study with Ficoll, iodixanol and dextran. Islets. 2011;3(4):144-9.

77. Bock T, Pakkenberg B, Buschard K. Genetic background determines the size and structure of the endocrine pancreas. Diabetes. 2005:54(1):133-7.

78. Bock T, Pakkenberg B, Buschard K. Increased islet volume but unchanged islet number in ob/ob mice. Diabetes. 2003:52(7):1716-22.

79. Inuwa IM, El Mardi AS. Correlation between volume fraction and volumeweighted mean volume, and between total number and total mass of islets in post-weaning and young Wistar rats. J Anat. 2005;206(2):185-92.

80. Lifson N, Lassa CV, Dixit PK. Relation between blood flow and morphology in islet organ of rat pancreas. Am J Physiol. 1985;249(1 Pt 1):E43-8.

81. Hellman B. The numerical distribution of the islets of Langerhans at different ages of the rat. Acta Endocrinol (Copenh). 1959;32:63-77. 
82. de Groot M, de Haan BJ, Keizer PPM, Schuurs TA, van Schilfgaarde R, Leuvenink HGD. Rat islet isolation yield and function are donor strain dependent. Lab Anim. 2004;38(2):200-6.

83. Dolenšek J, Rupnik MS, Stožer A. Structural similarities and differences between the human and the mouse pancreas. Islets. 2015;7(1):e1024405.

84. Street CN, Lakey JR, Shapiro AM, Imes S, Rajotte RV, Ryan EA, Lyon JG, Kin T, Avila J, Tsujimura T, Korbutt GS. Islet graft assessment in the Edmonton Protocol: implications for predicting long-term clinical outcome. Diabetes. 2004;53(12):3107-14

85. Huang $\mathrm{H}-\mathrm{H}$, Harrington S, Stehno-Bittel L. The Flaws and Future of Islet Volume Measurements. Cell Transplant. 2018;27(7):1017-26.

86. Andersson A. Isolated mouse pancreatic islets in culture: effects of serum and different culture media on the insulin production of the islets. Diabetologia. 1978;14(6):397-404.

87. Efanova IB, Zaitsev SV, Zhivotovsky B, Kohler M, Efendic S, Orrenius S, Berggren PO. Glucose and tolbutamide induce apoptosis in pancreatic beta-cells. A process dependent on intracellular $\mathrm{Ca} 2+$ concentration. J Biol Chem. 1998;273(50):33501-7.

88. Robertson RP, Harmon J, Tran PO, Tanaka Y, Takahashi H. Glucose toxicity in -cells: type 2 diabetes, good radicals gone bad, and the glutathione connection. Diabetes. 2003;52(3):581-7.

89. Ebrahimi AG, Hollister-Lock J, Sullivan BA, Tsuchida R, Bonner-Weir S, Weir GC. Beta cell identity changes with mild hyperglycemia: Implications for function, growth, and vulnerability. Mol Metab. 2020;35:100959.

90. Holmes MA, Clayton HA, Chadwick DR, Bell PR, London NJ, James RF. Functional studies of rat, porcine, and human pancreatic islets cultured in ten commercially available media. Transplantation. 1995;60(8):854-60.

91. Gaber AO, Fraga D. Advances in long-term islet culture: the Memphis experience. Cell Biochem Biophys. 2004;40(3 Suppl):49-54.

92. Gilon P, Jonas JC, Henquin JC. Culture duration and conditions affect the oscillations of cytoplasmic calcium concentration induced by glucose in mouse pancreatic islets. Diabetologia. 1994;37(10):1007-14.

93. Benninger RKP, Head WS, Zhang M, Satin LS, Piston DW. Gap junctions and other mechanisms of cell-cell communication regulate basal insulin secretion in the pancreatic islet. J Physiol. 2011;589(Pt 22):5453-66.

94. Loppini A, Pedersen MG. Gap-junction coupling can prolong beta-cell burst period by an order of magnitude via phantom bursting. Chaos Woodbury N. 2018;28(6):063111.

95. Benninger RKP, Hutchens T, Head WS, McCaughey MJ, Zhang M, Le Marchand SJ, Satin LS, Piston DW. Intrinsic islet heterogeneity and gap junction coupling determine spatiotemporal $\mathrm{Ca}^{2+}$ wave dynamics. Biophys J. 2014;107(11):2723-33.

96. Rodriguez-Diaz R, Molano RD, Weitz JR, Abdulreda MH, Berman DM, Leibiger B, Leibiger IB, Kenyon NS, Ricordi C, Pileggi A, Caicedo A, Berggren P-O. Paracrine Interactions within the Pancreatic Islet Determine the Glycemic Set Point. Cell Metab. 2018;27(3):549-558.e4.

97. Arrojo E, Drigo R, Jacob S, García-Prieto CF, Zheng X, Fukuda M, Nhu HTT, Stelmashenko O, Peçanha FLM, Rodriguez-Diaz R, Bushong E, Deerinck T, Phan S, Ali Y, Leibiger I, Chua M, Boudier T, Song S-H, Graf M, Augustine GJ, Ellisman $\mathrm{MH}$, Berggren P-O. Structural basis for delta cell paracrine regulation in pancreatic islets. Nat Commun. 2019;10(1):3700.

98. Scarl RT, Corbin KL, Vann NW, Smith HM, Satin LS, Sherman A, Nunemaker CS. Intact pancreatic islets and dispersed beta-cells both generate intracellular calcium oscillations but differ in their responsiveness to glucose. Cell Calcium. 2019;83:102081.

99. Scarl RT, Koch, WJ, Corbin, KL, Nunemaker CS. Isolation and assessment of pancreatic islets versus dispersed beta cells: a straightforward approach to examine cell-cell communication. In: Cell-Cell Communication: Methods and Protocols. 2nd ed. Methods Mol Biol. 2020. https://doi.org/10.1007/7651_ 2020 338. Online ahead of print. PMID: 33319334

100. Cui Y-F, Ma M, Wang G-Y, Han D-E, Vollmar B, Menger MD. Prevention of core cell damage in isolated islets of Langerhans by low temperature preconditioning. World J Gastroenterol. 2005;11(4):545-50.

101. Yasunami $Y$, Lacy PE, Davie JM, Finke EH. Prolongation of islet xenograft survival (rat to mouse) by in vitro culture at 37 C. Transplantation. 1983; 35(4):281-4.

102. Barnett MJ, McGhee-Wilson D, Shapiro AMJ, Lakey JRT. Variation in human islet viability based on different membrane integrity stains. Cell Transplant. 2004;13(5):481-8.

103. Vermes I, Haanen C, Steffens-Nakken H, Reutelingsperger C. A novel assay for apoptosis. Flow cytometric detection of phosphatidylserine expression on early apoptotic cells using fluorescein labelled Annexin V. J Immuno Methods. 1995;184(1):39-51.

104. Miyamoto M, Morimoto Y, Nozawa Y, Balamurugan AN, Xu B, Inoue K Establishment of fluorescein diacetate and ethidium bromide (FDAEB) assay for quality assessment of isolated islets. Cell Transplant. 2000;9(5):681-6.

105. Iurlaro R, Muñoz-Pinedo C. Cell death induced by endoplasmic reticulum stress. FEBS J. 2016;283(14):2640-52.

106. Barbu A, Welsh N, Saldeen J. Cytokine-induced apoptosis and necrosis are preceded by disruption of the mitochondrial membrane potential (Deltapsi(m)) in pancreatic RINm5F cells: prevention by Bcl-2. Mol Cell Endocrinol. 2002;190(1-2):75-82.

107. Hughes KJ, Chambers KT, Meares GP, Corbett JA. Nitric oxides mediates a shift from early necrosis to late apoptosis in cytokine-treated beta-cells that is associated with irreversible DNA damage. Am J Physiol Metab. 2009; 297(5):E1187-96.

108. Dula SB, Jecmenica M, Wu R, Jahanshahi P, Verrilli GM, Carter JD, Brayman $\mathrm{KL}$, Nunemaker CS. Evidence that low-grade systemic inflammation can induce islet dysfunction as measured by impaired calcium handling. Cell Calcium. 2010;48(2-3):133-42.

109. O'Neill CM, Lu C, Corbin KL, Sharma PR, Dula SB, Carter JD, Ramadan JW, Xin W, Lee JK, Nunemaker CS. Circulating Levels of IL-1B+IL-6 Cause ER Stress and Dysfunction in Islets From Prediabetic Male Mice. Endocrinology. 2013; 154(9):3077-88

110. Gelin L, Li J, Corbin KL, Jahan I, Nunemaker CS. Metformin Inhibits Mouse Islet Insulin Secretion and Alters Intracellular Calcium in a ConcentrationDependent and Duration-Dependent Manner near the Circulating Range. J Diabetes Res 2018;2018:9163052.

111. Eizirik DL, Pasquali L, Cnop M. Pancreatic $\beta$-cells in type 1 and type 2 diabetes mellitus: different pathways to failure. Nat Rev Endocrinol. 2020; 16(7):349-62.

112. English A, Irwin N. Nonclassical Islet Peptides: Pancreatic and Extrapancreatic Actions. Clin Med Insights Endocrinol Diab. 2019;12:1179551419888871.

113. Nolan AL, O'Dowd JF. The measurement of insulin secretion from isolated rodent islets of Langerhans. Methods Mol Biol Clifton NJ. 2009:560:43-51.

114. Truchan NA, Brar HK, Gallagher SJ, Neuman JC, Kimple ME. A single-islet microplate assay to measure mouse and human islet insulin secretion. Islets. 2015;7(3):e1076607.

115. Slepchenko KG, Corbin KL, Nunemaker CS. Comparing methods to normalize insulin secretion shows the process may not be needed. J. Endocrinol. 2019. https://doi.org/10.1530/JOE-18-0542.

116. Rutter GA, Hodson DJ, Chabosseau P, Haythorne E, Pullen TJ, Leclerc I. Local and regional control of calcium dynamics in the pancreatic islet. Diabetes Obes Metab. 2017;19(Suppl 1):30-41.

117. Takahashi A, Camacho P, Lechleiter JD, Herman B. Measurement of intracellular calcium. Physiol Rev. 1999;79(4):1089-125.

118. Paredes RM, Etzler JC, Watts LT, Zheng W, Lechleiter JD. Chemical calcium indicators. Methods San Diego Calif. 2008;46(3):143-51.

119. Demaurex N, Frieden M. Measurements of the free luminal ER Ca(2+) concentration with targeted "cameleon" fluorescent proteins. Cell Calcium. 2003;34(2):109-19.

120. Zhou Y, Wang Y, Gill DL. Assessing the Molecular Nature of the STIM1/Orai1 Coupling Interface Using FRET Approaches. In: Kozak JA, Putney JW, editors. Calcium Entry Channels in Non-Excitable Cells. Boca Raton (FL): CRC Press/ Taylor \& Francis; 2018. Available at: http://www.ncbi.n/m.nih.gov/books/ NBK531425/. Accessed July 16, 2020.

121. Ramadan JW, Steiner SR, O'Neill CM, Nunemaker CS. The central role of calcium in the effects of cytokines on beta-cell function: implications for type 1 and type 2 diabetes. Cell Calcium. 2011;50(6):481-90

122. Gilon $P$, Chae HY, Rutter GA, Ravier MA. Calcium signaling in pancreatic beta-cells in health and in Type 2 diabetes. Cell Calcium. 2014.

123. Idevall-Hagren $\mathrm{O}$, Tengholm A. Metabolic regulation of calcium signaling in beta cells. Semin Cell Dev Biol. 2020;103:20-30.

124. Corbin KL, Hall TE, Haile R, Nunemaker CS. A novel fluorescence imaging approach for comparative measurements of pancreatic islet function in vitro. Islets. 2011;3(1):14-20.

125. Qureshi FM, Dejene EA, Corbin KL, Nunemaker CS. Stress-induced dissociations between intracellular calcium signaling and insulin secretion in pancreatic islets. Cell Calcium. 2015:57(5-6):366-75.

126. Henquin JC, Bozem M, Schmeer W, Nenquin M. Distinct mechanisms for two amplification systems of insulin release. Biochem J. 1987; 246(2):393-9. 
127. Ammala C, Ashcroft FM, Rorsman P. Calcium-independent potentiation of insulin release by cyclic AMP in single beta-cells. Nature. 1993;363(6427): 356-8.

128. Kalwat MA, Cobb MH. Mechanisms of the amplifying pathway of insulin secretion in the beta cell. Pharmacol Ther. 2017;179:17-30.

\section{Publisher's Note}

Springer Nature remains neutral with regard to jurisdictional claims in published maps and institutional affiliations.

\section{Ready to submit your research? Choose BMC and benefit from:}

- fast, convenient online submission

- thorough peer review by experienced researchers in your field

- rapid publication on acceptance

- support for research data, including large and complex data types

- gold Open Access which fosters wider collaboration and increased citations

- maximum visibility for your research: over $100 \mathrm{M}$ website views per year

At $\mathrm{BMC}$, research is always in progress. 